\title{
Barriers to effective circular supply chain management in a developing country context
}

\author{
Sachin Kumar Mangla ${ }^{1}$, Sunil Luthra ${ }^{2}$, Nishikant Mishra ${ }^{3}$, Akshit Singh $^{4}$, Nripendra P. \\ Rana $^{5}$, Manoj Dora ${ }^{6}$ and Yogesh Dwivedi ${ }^{7}$ \\ ${ }^{1}$ Department of Mechanical Engineering, Graphic Era University, Dehradun, Uttarakhand, India. \\ Email: Sachinmangl@gmail.com \\ ${ }^{2}$ Department of Mechanical Engineering, Government Engineering College, Nilokheri, Haryana, India. \\ Email: Sunilluthra1977@gmail.com \\ ${ }^{3}$ Hull University Business School, University of Hull, United Kingdom. Email: Mishra09@gmail.com \\ ${ }^{4}$ Alliance Manchester Business School, University of Manchester, United Kingdom. \\ Email: Akshit.Singh@manchester.ac.uk \\ ${ }^{5}$ School of Management, Swansea University, United Kingdom. Email: nrananp@gmail.com \\ ${ }^{6}$ Brunel Business School, Brunel University London, United Kingdom. Email: Manoj.Dora@brunel.ac.uk \\ ${ }^{7}$ School of Management, Swansea University, United Kingdom. Email: ykdwivedi@gmail.com
}

\begin{abstract}
Circular supply chain emphasizes surge in application of reuse, recycling and remanufacturing and thereby promotes the transformation of manufacturing characteristics from linear ('take-produce-utilize-dump') to circular model of flow of products, by-products and waste. Supply chains of manufacturing industries have become global in last few decades. Products manufactured in developing nations like India and China are being sent to developed nations for consumption in higher volumes. Developed nations have the regulatory policies, technological knowhow and modern infrastructure to adopt circular supply chain model. Their counterpart is trailing in these aspects. In literature, limited research work has been performed on identifying challenges of implementing circular supply chain management in developing nations and their contextual association. In this article, based on thorough literature review and feedback received from experts, sixteen important barriers were identified to circular supply chain management adoption in Indian context. The listed barriers were then analysed using an integrated Interpretive Structural Modelling - MICMAC approach. This study attempts to identify the contextual interactions among identified barriers and to examine their hierarchical levels in effective adoption and implementation of circular supply chain management. The findings of this research will contribute in transforming
\end{abstract}


supply chains in terms of bringing economic prosperity, addressing global warming issues and generating numerous employment opportunities. Finally, some crucial policy measures and recommendations are proposed to assist managers and government bodies to adopt and manage the concepts of circular supply chains effectively in Indian context.

Keywords: Barriers; Circular Economy (CE); Circular Supply Chain Management (CSCM); Interpretive Structural Modelling (ISM); MICMAC analysis.

\section{Introduction}

In the recent years, organisations are seeking to methodically approaching circular supply chain models to their businesses in terms of extending the product life cycle, managing the waste, developing economy sustainability by inclination of customer preferences towards secondary goods and products etc. In developing economy sustainability, Circular Economy $(\mathrm{CE})$ is an appropriate strategy that proposes novel means to transform the traditional system (consumption at customers end) into a circular system (Stahel, 2013). CE helps in addressing the issues of ecological degradation and resource scarcity in an industrial context (Geng et al., 2009). This situation will be intensified when extremely high demand for goods and services are anticipated as three-billion consumers are expected to enter the worldwide market by 2030 (Ellen MacArthur Foundation, 2014). To deal with this, "business as usual" approach, where stakeholders take, manufacture, use, and dispose goods is not a sufficient choice for manufactures (Williams, 2001). Thus, it is needed to transform the whole supply chain in terms of product designing and manufacturing etc (Low et al., 2016). A circular supply chain (CSC) represents to a restorative production system, where resources, enter an infinite loop of reuse, remanufacturing and recycling. Circular Supply Chain Management (CSCM) belongs to circular economy that aims to optimize the resources utilization throughout the product life cycle by means of recycling remanufacturing, etc. (Genovese et al., 2017). CSC/CSCM may also be a good solution to alleviate problems such as pollution, unattainable patterns of production and consumption, resource scarcity and climate change. This is due to the reason that by adopting circular model of flow of products, material and waste, organisations would be capable of reducing wastes and negative environmental impacts in the supply chain practices (Nasir et al., 2017; Genovese et al., 2017).

CSCM being a new emerging research area in literature, it is timely to examine the research and novel activities to help industry in developing their approach and the essential techniques/methods to adopt circular supply models effectively (Govindan et al., 2015). 
The majority of the population resides in developing countries. By 2050, the developing countries will account for more than $90 \%$ of the world's people. The concentration of population in under developed countries poses a significant challenge and need for systemic intervention because the concept of circular economy is rather new for the developing countries as compared to the developed countries (Goyal et al., 2016). Waste management is important aspect in the world where majority of the problems is faced by most of the Asian countries. Huge amount of resources are being depleted especially in India through improper waste handling leading to unsustainable waste management practices (Esfahbodi et al., 2016; Ghosh, 2016). Current waste management practices employed by India are inadequate to manage large amounts of waste generated on a daily basis. The presence of waste is an indication of overconsumption, inefficient use of materials, and poor waste disposal mechanisms (Vladimirova, 2016; Yaduvanshi et al., 2016). There is an urgent need to develop and sustain a circular supply models.

Keeping the aforementioned issues in mind, implementing CSCM practices is not easy task because it is hindered by numerous barriers (Goyal et al., 2016; Yaduvanshi et al., 2016). This research work helps managers/practitioners to achieve the following objectives:

- To identify the key barriers relevant to CSCM implementation;

- To examine the contextual relationships between the identified barriers and their hierarchical levels relevant to CSCM implementation;

- To develop an interpretive structural model to understand the dynamics of barriers to overcome these identified barriers towards effective implementation of CSCM practices.

This work is an initial effort that proposes an integrated Interpretive Structural Modeling (ISM) and MICMAC approach to identify and analyze the barriers to CSCM implementation in a devloping country context, especially India. Literature review and experts' inputs were used to identify the relevant key barriers. This is a problem of the multi-attribute decision type. ISM-MICMAC approach helps to develop a hierarchy structure of barriers by recognizing their contextual relationships and driving potential and dependencies (Kumar et al., 2016).

This work attempts to make several contributions to the literature, which are described below: 
- Firstly, this study generates relevant barriers to CSCM adoption in an Indian context. The barriers listed can serve as a foundation that comprehensively cover possible hurdles linked to effective adoption and implementation of CSCM in India.

- Secondly, in the context of contributing to the theory, the integrated ISM-MICMAC based model is suggested to analyse the barriers to CSCM implementation. The methodological framework is logically sound to analyse the barriers.

- Thirdly, this research provides a benchmarking framework to assist managers and government bodies in formulating decisive policies in effectively managing the circular models related problematic issues at the industrial context.

The remainder of this paper is organized as follows. The review of related literature for this work is discussed in Section 2. Section 3 proposes the research methods. Section 4 describes the proposed model for this research. The data analysis and results are presented in Section 5. Results along with the policy recommendations are discussed in Section 6. Finally, Section 7 provides conclusions, unique contributions, limitations and the scope for future research.

\section{Literature Survey}

The present section covers the previous studies on CE/CSC and CSCM, and explores the barriers in implementation of CSCM as well. For reviewing the literature, we adopt the Systematic Literature Review (SLR) approach of Gunasekaran et al., (2015) and Glock (2016). All co-authors work together during the literature survey for a common ground. Current and relevant papers were selected based on the following criteria:

(1) Papers should include Circular Economy/Circular Supply Chain and Circular Supply Chain Management implementation in the supply chain. However, the keywords used for data collection include "Supply Chain", "Circular Economy", "Environmental", "Circular Supply Chain", "Circular Supply Chain Management", "Closed Loop Supply Chain", "Sustainability", "Barriers". Combinations of these keywords were used including (1) Circular Economy and Supply Chain and Barriers, (2) Environmental and Circular Economy and Supply Chain and Barriers, (3) Environmental and Circular Supply Chain Management and Barriers, (4) Sustainability and Circular Economy and Supply Chain and Barriers.

(2) Google Scholar, Scopus, ScienceDirect, Taylor and Francis, Emerald and Springer search databases were explored to collect research articles. The collected studies were analysed using the keywords in abstract and main text of article to include/exclude a particular article. 
In addition, a refining criteria is being followed for inclusion/exclusion of the articles, which are given as (i) Articles written in English language were only considered; (ii) peer-reviewed journals articles and book chapters, were only considered (conference proceedings were excluded). Various journals which were targeted for collecting the articles are - International Journal of Production Research, International Journal of Production Economics, Journal of Cleaner Production, Production Planning \& Control, Journal of Environmental Management, Supply Chain Management: An International Journal, European Journal of Operation Research, Omega and Waste Management Journals etc.

Considering these criteria, the collected literature is scrutinized as per the forward snowball and backward snowball technique (Glock et al., 2014). This process helps to extract only those articles, which are relevant to this study. All articles were considered to be representative of the current body of knowledge associated with CE/CSC, CSCM adoption and implementation, and barriers and challenges related to CSCM.

Further, a review on the articles carried out for this work is given in the subsequent subsections.

\subsection{CE/CSC and CSCM}

The linear economic model driven by a "take-make-dispose" philosophy is unable to manage the demand and supply balance in consumption of natural resources. This imbalance is affecting the sustainability of the nations and enterprises as well as affecting the global supply chain leading to socioeconomic and environmental risks and volatility. Realizing the future resource scarcity challenge, the current linear economy model is giving way to the circular supply model (George et al., 2015; Goyal et al., 2016). Pearce and Turner (1990) based on the introductory concept of circular economic system building by ecological economist Boulding (1966). The concept of CE was addressed by the Rio+20 summit as "one of the important tools available for achieving sustainable development". It has been stated that circular and green economy also "contribute to eradicating poverty as well as sustained economic growth, enhancing social inclusion, improving human welfare and creating opportunities for employment and decent work for all, while maintaining the healthy functioning of the Earth's ecosystems". The CE model has been actualized at three levels, to be specific, eco-regions at the full scale level, eco-industrial parks at the meso-level, and ecoenterprises at the small scale level (Yuan et al., 2006), with the objective of incorporating monetary development with ecological sustainability (Wang et al., 2010; Zhu et al., 2011). Further, due to high industrial growth and modernization, organisations across all over the 
world are facing the issues related to the negative environmental impact of their business activities. In response, managers are seeking to develop some innovative methods and approaches to manage these concerns. The circular initiatives in supply chain are becoming increasingly popular to address these issues (Geng et al., 2012). The CSCM can be understood as the approach that keeps resources in use as long as possible; and that reduces waste at every stage, from design to distribution and beyond (Subramanian and Gunasekaran, 2015). During implementation of CSCM, the transformation of linear manufacturing chains to circular chains should proceed in such a way that the business network models capable to manage the streamline circular flow of both the products and of by-products/waste generated (Loombaa and Nakashima, 2012).

On the one hand, the scope of implementation of CSC initiatives is extended among business organisations, because CSCM initiatives may provide a sensible linkage between their economic growth, and resource depletion and community welfare issues, and hence offer opportunities for sustainability of business (Park et al., 2010), on the other hand, in today's scenario of complex environment, the adoption and extension of CSC models for sustainability of business is challenging and needs a comprehensive understanding and theory building (Dora et al., 2016). In this sense, it is important to explore the concepts of CE/CSC and CSCM for improving ecological-economic-social performance of industrial supply chains. Based on previous studies, researchers and practitioners all around the world aims to address the perspectives of circular supply models in a supply chain context (Goyal et al., 2016; Genovese et al., 2017). Literature also suggested that there are various challenges associated with the implementation of CSCM concepts, which needs to be distinguished accurately along with the scaling up of their solutions from the industrial viewpoints (Geng and Doberstein, 2008; Geng et al., 2012; Su et al., 2013; Goyal et al., 2016; Genovese et al., 2017; Nasir et al., 2017). In the next subsection, the barriers to CSCM are identified.

\subsection{CSCM related barriers}

Business organisations are facing substantial upfront investments to implement CSC concepts and are depending their suppliers and retailers to collaborate, as all value chain partners have to be involved (Dora et al., 2016). In addition, circularity extends the end-of-life phase for products resulting in decreased revenues at constant customer volumes. Consumers also face challenges in adoption of circular models. In line with this, suppliers and manufacturers are also facing various problematic issues in CSCM adoption. Some of them are - lack of knowledge of the concept, economic constraints, management approach etc. Hence, the 
recognition and analysis of related hurdles in adopting CSCM concepts should be explored comprehensively. In this work, a total of 16 barriers relevant to CSCM adoption were identified through the extensive literature support. The identified barriers were validated through inputs received from the experts, and other details regarding data collection are given in Section 5.1. The identified barriers to implement CSCM concepts are explained in Table 1, as below.

Table 1: Barriers to implement CSCM concepts

\begin{tabular}{|c|c|c|}
\hline Barriers & Description & References \\
\hline $\begin{array}{lr}\text { Lack of } & \text { industry } \\
\text { incentives } & \text { for } \\
\text { 'greener' } & \text { activities } \\
\text { (B1) } & \end{array}$ & $\begin{array}{l}\text { Environmental costs are increasing rapidly for industries, with } \\
\text { little chance of economic payback in sight. The } \\
\text { financial incentives for industries are necessary to invest } \\
\text { in green/circular concepts. An incentive from governmental } \\
\text { bodies for promoting the CCS is lacking to develop } \\
\text { sustainable/regenerative goods. Lack of financial support } \\
\text { mechanism for 'greener' activities is an important hurdle in } \\
\text { case of developing countries, as they are lacking in } \\
\text { implementation of green and/or circular models compared to } \\
\text { developed countries in terms of advanced technologies and } \\
\text { green transformation in manufacturing. }\end{array}$ & $\begin{array}{l}\text { Geng and Doberstein } \\
(2008) ; \mathrm{Su} \text { et al., } \\
(2013) ; \mathrm{Li} \text { et al., } \\
\text { (2015); Mangla et al., } \\
\text { (2015); Prendeville et } \\
\text { al., (2016) }\end{array}$ \\
\hline $\begin{array}{l}\text { Lack of } \\
\text { environmental laws } \\
\text { and regulations (B2) }\end{array}$ & $\begin{array}{l}\text { In the view of increased energy demand, ecological issues and } \\
\text { carbon emissions, the government agencies must frame } \\
\text { stringent environmental laws and regulations. Developing } \\
\text { nations, like India does not have a strong environmental } \\
\text { regulatory structure to adopt circular supply models compared } \\
\text { to their western counter parts and developed nations. }\end{array}$ & $\begin{array}{l}\text { Goyal et al., 2016; } \\
\text { Venkatesh } \\
\text { Luthra (2016); Zhu et } \\
\text { al., (2017) }\end{array}$ \\
\hline $\begin{array}{l}\text { Lack of } \\
\text { Management } \\
\text { commitment and } \\
\text { approach for CSCM } \\
\text { adoption (B3) }\end{array}$ & $\begin{array}{l}\text { Ecological transformations and improvements are primarily } \\
\text { driven by a committed managerial approach for sustainable } \\
\text { development. A comprehensive CE framework followed by a } \\
\text { practical implementation strategy is required to implement } \\
\text { CSCM concepts, which could be possible only with } \\
\text { management support and dedicated approach. However, in real } \\
\text { practice, the management fails to do so. Thus, lack of } \\
\text { management commitment is perceived as one of the important } \\
\text { barriers for CSCM adoption. }\end{array}$ & $\begin{array}{l}\text { Giunipero et al., } \\
\text { (2012); Zhu and } \\
\text { Geng, (2013); Rizos } \\
\text { et al., (2015); } \\
\text { Venkatesh } \\
\begin{array}{l}\text { Luthra, } \\
\text { Lieder and } \\
(2016)\end{array}\end{array}$ \\
\hline $\begin{array}{l}\text { Lack of preferential } \\
\text { tax policies for } \\
\text { promoting the } \\
\text { circular models (B4) }\end{array}$ & $\begin{array}{l}\text { Preferential loans and tax benefits for energy saving and waste } \\
\text { reduction may help to promote CSC concepts. However, } \\
\text { preferential tax policies have been used on temporary basis and } \\
\text { in very limited scale in India. The lack of government } \\
\text { motivation and support (via ineffective tax policies, import and } \\
\text { excise duty, etc.) is usually documented as an important hurdle } \\
\text { during circular concepts adoption. }\end{array}$ & $\begin{array}{l}\text { Geng and Doberstein, } \\
(2008) \text {; Wang et al., } \\
(2010) \text {; Tripathi et } \\
\text { al., (2016) }\end{array}$ \\
\hline $\begin{array}{ll}\text { Lack } & \text { of } \\
\text { implementation } & \text { of } \\
\text { environmental } & \\
\text { management } \\
\text { certifications and }\end{array}$ & $\begin{array}{l}\text { An environmental management system is considered as an } \\
\text { element of organisation's management system with an } \\
\text { objective to manage the environmental aspects. Business } \\
\text { organisations pay lesser attention to regulations, and thus are } \\
\text { more reluctant to implement proactive ecologically-friendly } \\
\text { concepts. Environmental management certifications and }\end{array}$ & $\begin{array}{l}\text { Massoud et al., } \\
(2010) ; \quad \text { Guerrero- } \\
\text { Baena et al., (2015); } \\
\text { Pan et al., (2015) }\end{array}$ \\
\hline
\end{tabular}




\begin{tabular}{|c|c|c|}
\hline systems (B5) & $\begin{array}{l}\text { systems (ISO 14001) are still scarcely implemented, } \\
\text { incomprehensive and scattered especially in a developing } \\
\text { country, like India. }\end{array}$ & \\
\hline $\begin{array}{l}\text { Lack of middle and } \\
\text { lower level } \\
\text { managers' support } \\
\text { and involvement in } \\
\text { promoting 'greener' } \\
\text { products (B6) }\end{array}$ & $\begin{array}{l}\text { The support of lower and middle level managers is significant } \\
\text { in accepting CSC concepts. In adopting successful circular } \\
\text { models for improving its ecological responsibilities in supply } \\
\text { chains, all of the supply chain managers and experts within and } \\
\text { across the department needs to work collectively. Lack of } \\
\text { middle and lower level managers' support and involvement in } \\
\text { promoting 'greener' products can lead to failure of the entire } \\
\text { system. }\end{array}$ & $\begin{array}{l}\text { Zhu et al., (2008); } \\
\text { Zhu et al., (2010); } \\
\text { Kumar and } \\
\text { Chandrakar, (2012); } \\
\text { Papadopoulos et al., } \\
\text { (2017) }\end{array}$ \\
\hline $\begin{array}{l}\text { Lack of customer } \\
\text { awareness and } \\
\text { participation around } \\
\text { CSC activities (B7) }\end{array}$ & $\begin{array}{l}\text { The promotion of customer responsibility is crucial for } \\
\text { enhancing their purchasing preferences and use of more } \\
\text { sustainable products and services. From organisational } \\
\text { viewpoints, unawareness on the circular models illustrates a } \\
\text { message of 'lack of involvement of public perception and } \\
\text { views' and which can hinder the acceptance of circular models } \\
\text { in the supply chain. }\end{array}$ & $\begin{array}{l}\text { Kumar and } \\
\text { Malegeant, (2006); } \\
\text { Pan et al., (2015); } \\
\text { Rizos et al., (2015); } \\
\text { Ghisellini et al., } \\
\text { (2016); Genovese et } \\
\text { al., (2017) }\end{array}$ \\
\hline $\begin{array}{l}\text { Poor demand/ } \\
\text { acceptance for } \\
\text { environmentally } \\
\text { superior } \\
\text { technologies (B8) }\end{array}$ & $\begin{array}{l}\text { Highly developed technology and updating of equipment and } \\
\text { facilities provides a way to accomplish circular supply } \\
\text { initiatives in supply chains. However, environmentally superior } \\
\text { technologies demand is not satisfactory especially in a } \\
\text { developing country, like India; this results in increased } \\
\text { pollution and energy scarcity and decreased financial gains. }\end{array}$ & $\begin{array}{l}\text { Geng and Doberstein, } \\
(2008) \text {; Su et al., } \\
(2013)\end{array}$ \\
\hline technology & $\begin{array}{l}\text { Societies all over the world are facing the issues of ecological } \\
\text { degradations, resources depletion, climate change and many } \\
\text { related problems. The effective measure to tackle these issues } \\
\text { could be either development of new technologies or technology } \\
\text { transfers. Technology transfer involves the transfer of latest } \\
\text { technology from the inventor (developed nation) to a } \\
\text { secondary user (developing country) to improve effectiveness } \\
\text { towards CSC initiatives. Thus, the transfer of technology may } \\
\text { be an effective decision choice for a developing nation like } \\
\text { India in this situation. }\end{array}$ & $\begin{array}{l}\text { Geng and Doberstein, } \\
\text { (2008); Kaushik et } \\
\text { al., (2014) }\end{array}$ \\
\hline $\begin{array}{l}\text { Inadequacy in } \\
\text { knowledge and } \\
\text { awareness of } \\
\text { organisational } \\
\text { members about } \\
\text { CSCM initiatives } \\
\text { (B10) }\end{array}$ & $\begin{array}{l}\text { The implementation of CSC concepts requires high scientific } \\
\text { skills, which are currently lacking in the context of an } \\
\text { organisational supply chain. This inadequacy in knowledge and } \\
\text { awareness of organisational members and related players } \\
\text { restricts organisational members in CSCM adoption in terms of } \\
\text { better product and network design of circular products to } \\
\text { promote higher re-use, recycle, remanufacture, repair etc. }\end{array}$ & $\begin{array}{l}\text { Benton et al., (2015); } \\
\text { Lieder and Rashid, } \\
\text { (2016); Gallaud and } \\
\text { Laperche, (2016) }\end{array}$ \\
\hline $\begin{array}{l}\text { Lack of appropriate } \\
\text { training and } \\
\text { development } \\
\text { programs for } \mathrm{SC} \\
\text { members and } \mathrm{HR} \\
\text { (B11) }\end{array}$ & $\begin{array}{l}\text { Skills would enable businesses to design products with } \\
\text { circularity in practices, and to engage in reuse, refurbishment } \\
\text { and recycling. Lack of capabilities of HR professionals and SC } \\
\text { members' (in terms of skills, knowledge, training and } \\
\text { development program), can be a crucial hurdle in effective } \\
\text { adoption and implementation of CSC concepts in an industrial } \\
\text { context. }\end{array}$ & $\begin{array}{l}\text { Visvanathan and } \\
\text { Kumar, (1999); del } \\
\text { Brio et al., (2008); } \\
\text { Zhu and Geng, } \\
\text { (2013); Lacy and } \\
\text { Rutqvist, (2015) }\end{array}$ \\
\hline $\begin{array}{lr}\text { Lack of effective } \\
\text { planning } & \text { and }\end{array}$ & $\begin{array}{l}\text { The adoption of CSCM concepts will require effective } \\
\text { planning and management, for the designing of scenarios for }\end{array}$ & $\begin{array}{l}\text { Geng and Doberstein, } \\
\text { (2008); Ceschin, }\end{array}$ \\
\hline
\end{tabular}




\begin{tabular}{|c|c|c|}
\hline $\begin{array}{l}\text { management for } \\
\text { CSCM concepts } \\
\text { (B12) }\end{array}$ & $\begin{array}{l}\text { the optimal utilization of resources (reuse, repair, recycling, } \\
\text { and remanufacturing). Any inadequacy in the planning and } \\
\text { management (sufficient differentiation between reuse, } \\
\text { recycling, remanufacturing) may mislead supply chain players } \\
\text { to focus on the critical issues in CSCM adoption. }\end{array}$ & $\begin{array}{l}\text { (2013); Nasir et al., } \\
\text { (2017) }\end{array}$ \\
\hline $\begin{array}{l}\text { Lack of systematic } \\
\text { information systems } \\
\text { (B13) }\end{array}$ & $\begin{array}{l}\text { The structure of supply chain is very complex at the } \\
\text { organisational levels. In this sense, it is needed to design and } \\
\text { follow an information system network based on the system } \\
\text { approach. The benefits of this could be listing superior } \\
\text { ecological and financial focused means to plan and manage } \\
\text { their resources. At the same time, to design and follow such } \\
\text { systematic information systems are generally lacking in a } \\
\text { developing country like India. }\end{array}$ & $\begin{array}{l}\text { Geng and Doberstein, } \\
\text { (2008); Pan et al., } \\
\text { (2015) }\end{array}$ \\
\hline $\begin{array}{l}\text { Lack of } \\
\text { coordination and } \\
\text { collaboration among } \\
\text { SC members (B14) }\end{array}$ & $\begin{array}{l}\text { Business organisations, depending on their vendors/suppliers } \\
\text { and retailers/distributors, need to collaborate and coordinate, as } \\
\text { all supply chain (SC) players need to be involved for higher } \\
\text { profits and market image. Collaboration and coordination is } \\
\text { also very important in the sense as it is not possible for a } \\
\text { business organisation to have in-house arrangements for } \\
\text { recycling, remanufacturing of all the by-products. }\end{array}$ & $\begin{array}{l}\text { Defee et al., (2009); } \\
\text { Zhu et al., (2013); } \\
\text { Zhu and Geng, } \\
(2013)\end{array}$ \\
\hline $\begin{array}{l}\text { Lack of support and } \\
\text { participation of } \\
\text { stakeholders (B15) }\end{array}$ & $\begin{array}{l}\text { In implementing CSCM concepts, managers must design the } \\
\text { system, which involves effective management of natural } \\
\text { resources and unbiased distribution of resources, by assuring } \\
\text { the active participation and support of all stakeholders. } \\
\text { Without the appropriate level of support and participation from } \\
\text { the stakeholders, it is complex to implement any innovation in } \\
\text { process/technology and streamline their efforts in CSCM } \\
\text { implementation. }\end{array}$ & $\begin{array}{l}\text { Geng and Doberstein, } \\
\text { (2008); Pan et al., } \\
\text { (2015); Tukker, } \\
\text { (2015); Miemczyk et } \\
\text { al., (2016) }\end{array}$ \\
\hline $\begin{array}{l}\text { Lack of economic } \\
\text { benefits in short-run } \\
\text { (B16) }\end{array}$ & $\begin{array}{l}\text { If an organisation focuses on environmental issues, then it } \\
\text { would definitely have some loss of economic value. A lack of } \\
\text { economic benefits in short-run can be understood as the } \\
\text { increasing short-term cost, which is always the initial internal } \\
\text { barrier in any decision-making. Hence, lack of economic } \\
\text { benefits in short-run is considered as a significant barrier in } \\
\text { CSCM adoption. }\end{array}$ & $\begin{array}{l}\text { Park et al., (2010); } \\
\text { Zhu and Geng, } \\
(2013)\end{array}$ \\
\hline
\end{tabular}

\subsection{Research gaps}

Natural resources are being depleted with a very high rate all across the globe due to unsustainable waste management practices, inefficient eco-design of products, and unnecessary wastage of useful materials during consumption, unsegregated wastes generation, transportation, unorganized recycling and reuse, ineffective treatment and ultimate disposal to dumpsite. To deal with these issues, resource recovery initiatives need to be established to develop and sustain circular models in the context of industrial supply chains (Ghosh, 2016). CSCM is a method of concurrently addressing the issues of energy demand, waste management and green house gas emissions to develop a CE system (Pan et al., 2015; Tukker, 2015). 
To date, many countries in the world (Japan, Austria, Germany, the Netherlands and China) have taken measures to promote the CSC concepts and already developed some extent strategies compatible with circular model activities (George et al., 2015). However, in emerging country like India, policy measures and strategies are yet missing due to many issues to implement CSC concepts (Subramanian and Gunasekaran, 2015).

India is one of the most populous country having $17 \%$ of the global population. The future risks associated with the increasing demand-supply gap is pertained to the growing population, increasing demand for resources, finite nature of resources, and linear economic model has led to interest in the adoption of the CSCM practices.

Besides, in the present era, Indian organisations are seeking to improve their products with respect to design, production methods and procedures, and delivery, to provide value to the customer and make them sustainable in the market. To achieve this, Indian organisations are adopting contemporary strategies in their supply chains such as Six Sigma, Lean, and green concepts, for sustainable business development (Kumar et al., 2016). In addition, some Indian organisations, which have adopted novel housekeeping practices, process orientation, or $5 \mathrm{~S}$ and supplier engagement, are those, which are on the threshold of a CE/CSC initiatives (Ashton and Shenoy, 2015). However, it is surprising that very limited industries in India are seeking for true circularization of its business (Shenoy, 2016). It is because of the reason that implementing the concepts of CSCM is associated with several challenges to both business organisations as well as customers (Geng and Doberstein, 2008; Zhu et al., 2010; Dora et al., 2016; Nasir et al., 2017). The literature also reveals the need for the research to identify and analyse barriers towards effective implementation of CSCM concepts in India for optimal resources usage and sustainable development (Goyal et al., 2016; Ghosh, 2016; Yaduvanshi et al., 2016). Literature also lacks studies based on comprehensive analysis of barriers to CSCM implementation from the managerial perspectives (Su et al., 2013; Goyal et al., 2016). Thus, to have an understanding on interactive relations among the barriers may assist industry managers to eradicate the recognized barriers in effective implementation of CSCM concepts. This will also improve their overall performance and results in sustained growth.

To fulfil the aforementioned research gap, we undertook this study to recognize and analyse barriers in effective implementation of CSCM concepts in Indian context. Initially, the important CSCM implementation barriers were recognized from the literature and validated in discussion with experts. Later, the finalized barriers were analysed to uncover the interactions among them in implementation of circular supply concepts, and positioned them 
into a hierarchical structural model using the well-accepted integrated ISM-MICMAC technique.

\section{Research Methodology}

For accomplishing the present research, the ISM and MICMAC techniques have been utilized as the research methodology. ISM identifies the contextual relationships among the CSCM implementation related barriers and helps in developing a structural model of these barriers. ISM is a methodical and interactive technique that relies on a group of experts (independent professionals) (Warfield, 1974) to analyse the interrelations among elements (Mathiyazhagan et al., 2013). ISM can illustrate the overall organisation and relations of a structural model. ISM is a well-established interactive learning process (Watson, 1978). ISM composed of three words, first, Interpretive as members of the decision group collectively establishes the direct and indirect interactions of the elements; Second, Structural as it facilitates to deduce the structure of complex issues or problems and based on the derived relationships between the system's variables; and Modelling as it delivers a diagraph model to depict the specific relationships and overall structure. MICMAC analysis explains and analyses key barriers on the basis of their driving power and dependencies.

Notably, several methods are available in literature, which can reveal the interdependencies among the variables as well as develop their structural hierarchy. Some of these techniques are Analytic Hierarchy Process (AHP), Analytic Network Process (ANP), DEMATEL, Graph theory, Structural Equation modeling (SEM) etc. A comparison of ISM with abovementioned research methods (Wagner and Neshat, 2010; Raj et al., 2010; Mathiyazhagan et al., 2013; Jakhar and Barua, 2014; Luthra et al., 2017) is provided in Table 2. 
Table 2: Comparison of ISM with AHP/ANP/DEMATEL/Graph theory/SEM

\begin{tabular}{|c|c|c|c|c|c|}
\hline $\begin{array}{l}\text { ISM- } \\
\text { MICMAC }\end{array}$ & DEMATEL & Graph Theory & AHP & ANP & SEM \\
\hline $\begin{array}{l}\text { ISM- } \\
\text { MICMAC } \\
\text { uncovers the } \\
\text { contextual } \\
\text { interactions } \\
\text { among } \\
\text { variables } \\
\text { based on their } \\
\text { driving } \\
\text { potential and } \\
\text { dependencies }\end{array}$ & $\begin{array}{l}\text { DEMATEL } \\
\text { helps to } \\
\text { uncovers the } \\
\text { causal } \\
\text { interactions } \\
\text { among the } \\
\text { variables } \\
\text { based on } \\
\text { their cause } \\
\text { and effect } \\
\text { groups }\end{array}$ & $\begin{array}{l}\text { Graph theory is } \\
\text { used to reveal the } \\
\text { interdependencies } \\
\text { among the } \\
\text { variables; } \\
\text { however, the } \\
\text { reliability of the } \\
\text { direction of the } \\
\text { edges in the } \\
\text { graphs } \\
\text { questionable }\end{array}$ & $\begin{array}{l}\text { AHP does not } \\
\text { provide any } \\
\text { interdependencies } \\
\text { between and } \\
\text { among the } \\
\text { variables, rather } \\
\text { used to draw the } \\
\text { hierarchical } \\
\text { structure of the } \\
\text { variables }\end{array}$ & $\begin{array}{l}\text { ANP can provide } \\
\text { interdependencies } \\
\text { between and } \\
\text { among the } \\
\text { variables; this } \\
\text { method is less } \\
\text { accepted due to its } \\
\text { complexity. }\end{array}$ & $\begin{array}{l}\text { SEM is an } \\
\text { "a priori" } \\
\text { method, } \\
\text { mainly used } \\
\text { for } \\
\text { theoretical } \\
\text { development } \\
\text { of the } \\
\text { model. } \\
\text { However, } \\
\text { SEM } \\
\text { requires a } \\
\text { large sample } \\
\text { size }\end{array}$ \\
\hline
\end{tabular}

From Table 2, we can infer that ISM-MICMAC technique is comparatively sound in revealing contextual interactions among the CSCM oriented barriers. ISM-MICMAC has also been well-accepted in literature (see Table 3).

Table 3: summary on ISM-MICMAC application areas

\begin{tabular}{|l|l|l|}
\hline S. No. & ISM-MICMAC application area & References \\
\hline 1 & Reverse logistics implementation & Ravi and Shankar, (2005) \\
\hline 2 & Green supply chain management implementation & $\begin{array}{l}\text { Mathiyazhagan et al., (2013); Mangla } \\
\text { et al., (2014) }\end{array}$ \\
\hline 3 & Green product recovery systems & Mangla et al., (2013) \\
\hline 4 & Third party logistics & Diabat et al., (2013) \\
\hline 5 & Total quality management implementation & Talib et al., (2011) \\
\hline 6 & Total productive maintenance implementation & Singh et al., (2014) \\
\hline 7 & Sustainable supply chain management & Luthra et al., (2015a) \\
\hline 8 & Implementation of Emission Trading System & Shen et al., (2016) \\
\hline 9 & Implementing green supply chain management practices & Agi and Nishant, (2017) \\
\hline 10 & $\begin{array}{l}\text { Sustainable supply chain management practices in the context } \\
\text { of oil and gas industries }\end{array}$ & Raut et al., (2017) \\
\hline
\end{tabular}

The integrated ISM-MICMAC analysis consists of several steps (Haleem et al., 2016), which are explained in relation to the objective of this work (to analyse the barriers in CSCM adoption), as follows: 
- Identify the variables in relation to the research problem (barriers in CSCM adoption). In identification of barriers, the review of literature and experts feedback is very important.

- Devise contextual interactions between listed barriers to CSCM by means of questionnaire and data collection.

- Establish pair-wise relations between identified barriers to develop structural selfinteraction matrix (SSIM). The opinions of experts are useful to establish pair-wise relations.

- Establish initial reachability matrix (IRM) with the help of SSIM through experts' opinions. After this, it is needed to test the transitivity to form final reachability matrix (FRM). For more details on transitivity, readers may refer the studies of Agarwal et al., (2007) and Mangla et al., (2013). Derive the driving and dependence power of each barrier by summation of entries in rows and columns in FRM respectively.

- Classify the FRM into various levels to develop an ISM structural hierarchy of listed barriers. For determining various levels, the reachability set and antecedent set are formed. In the reachability set, we clustered a particular barrier and the other barriers affected by that barrier. In the antecedent set, we combined a particular barrier and other barriers that affect this barrier. Further, the reachability set and antecedent set are combined and the intersection set was formed.

- Development of MICMAC analysis graph of identified barriers. MICMAC analysis is graph between the driving power and dependency power of the variables. According to the driving and dependence power of barriers, we classify the barriers into four different categories (autonomous, dependent, linkage, and drivers).

- Sketch a digraph of listed barriers based on the relations in FRM. The preliminary digraph including transitive links is obtained. It is generated by nodes and lines of edges. After removing the indirect links, a final digraph is developed. A digraph is used to represent the visual representation of the barriers and their interdependence.

- Form an ISM based structural model of barriers using digraph.

- Test the developed ISM model for any theoretical inconsistency. Consequently, it is suggested to take the necessary actions.

The flow chart of ISM-MICMAC for this work is shown in Figure 1. 


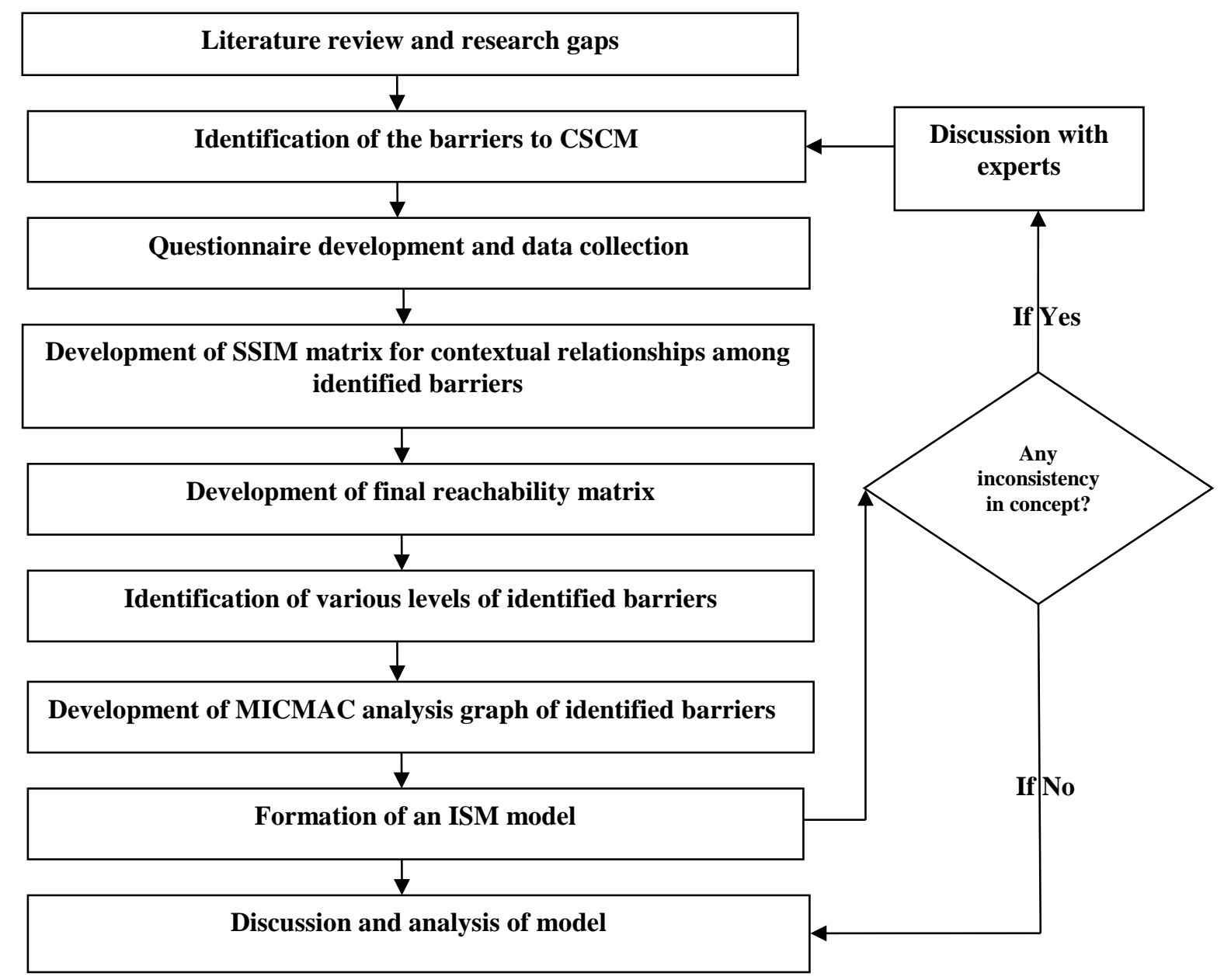

Figure 1: ISM-MICMAC Flowchart

\section{Proposed Research Framework}

In this section, we proposed a conceptual framework for analysing the recognized barriers relevant to CSCM implementation, as shown in Figure 2. This framework has both apparent scope of applicability and reliable nomenclature (Platts, 1990; Baines, 1994). This framework illustrates a real picture of the problem of adoption and implementation of CSCM in Indian context (Checkland and Scholes, 1990). Further, we grounded our research framework and its related processes on certain guidelines suggested by Platts, (1990), which are given as below-

i. The processes involved are related to existing framework. Collecting the literature, selecting the barriers and research methodology applicability all are linked to the purpose of this work.

ii. Each process in the framework are grounded on literature support and verified through and expert's feedback. The proposed research framework consists of two phases (see Figure 2). Phase 1 deal with the recognition and selection of the barriers 
relevant to CSCM implementation. The literature survey and experts' feedback were used to identify the relevant barriers. Initially, the barriers to implement CSC initiatives were identified through the literature review (see Section 2.2). The literature-based identified barriers were then finalized using experts' inputs (See Section 5.1). Phase 2 deals with the exploring contextual relations between the recognized barriers and developing their hierarchical levels to CSCM implementation. The ISM -MICMAC approach is used for this purpose (See Section 5.2). Notably, empirical testing of the processes in the framework is considered out of scope of the present work.

iii. Our research outcomes are useful to the managers and practitioners. The proposed framework can assist practicing managers in terms of: i) Selecting relevant barriers to CSCM implementation; ii) Uncovering contextual relationships between the barriers and developing hierarchical levels of barriers in CSCM implementation.

The detailed applicability and verification/validation of the processes involved in this framework is presented in the subsequent section.

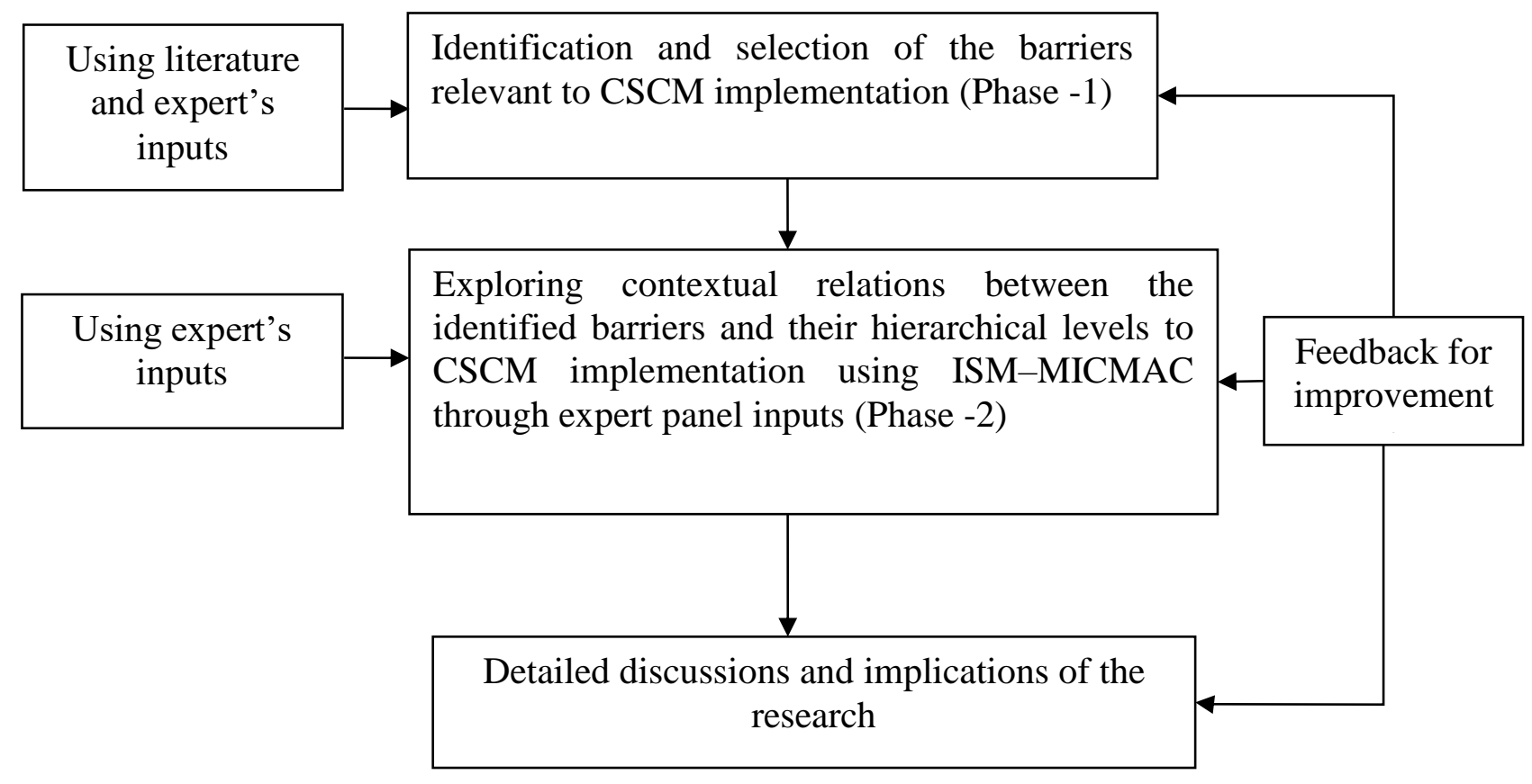

Figure 2: Proposed research framework 


\section{Application of the Proposed Research Framework}

The data needed for this work was collected from the 5 automotive manufacturing companies from the northern region of India. In order to collect the data, we contacted the 30 experts from various automotive manufacturing companies. The selection of the companies made on the basis of convenience sampling.

The data collection was not easy in this research, as we made several frequent phone calls and wrote several e-mails to follow up with the experts. Finally, seven experts out of thirty agreed to participate in the data collection process. In the same way, we contacted eight academicians, and four of them agreed to provide their responses. In this manner, an expert panel of 11 professionals was formed to analyse the barriers to CSCM adoption. This expert panel composed of one purchasing manager, one quality manager, three supply chain managers, two marketing managers, one environmental executive, three professors of operations management, and one professor of environmental science. The selected experts are highly skilled with respect to their qualification (postgraduate), knowledge and decision making. It should be noted that we selected the experts with a minimum of 10 years of experience in the domain. In addition, sample size taken for this work is sufficient and properly representative of the population under investigation because of issues of cost and time constraints. After this, we employed the proposed framework to the research problem under study with other details as below.

\subsection{Phase 1: Recognition and Selection of the Barriers Relevant to CSCM Implementation}

In this phase, the barriers related to CSCM adoption were finalized. A total of 16 barriers were listed through survey of literature. These barriers were then confirmed through expert panel inputs. For this, a brainstorming session was conducted with the consent of experts. The experts were asked to rate the listed barriers in CSCM adoption on 5 point Likert scale $(1=$ not at all, $2=$ somewhat significant, $3=$ significant, $4=$ very significant and $5=$ extremely significant). The experts were also asked to make any modification in the list of barriers; however, all the experts were agreed on the 16 literature based barriers and they have not made any modification in the list. In this way, all the identified barriers in CSCM were validated.

5.2 Phase 2: Exploring Contextual Relations between the Recognized Barriers and their Hierarchical Levels to CSCM Implementation using ISM-MICMAC through Expert Panel Inputs 
After selecting the barriers, the next task is to examine the contextual relations among the barriers. For this, we contacted the expert panel and gather the inputs received from the experts. As a further step, in order to analyse the barriers, we select a contextual relationship of "leads to" type meaning that one barrier leads to another barrier. The formation of contextual or comparison (pair wise) reveals the direction of relations between the barriers.

Keeping this in mind, we developed the contextual relations among the barriers (Kumar et al., 2016).

In addition, we used some symbols (Luthra et al., 2011), described as below.

$\mathrm{V}$ - Barrier $i$ will assist to reach for barrier $j$;

A - Barrier $j$ will assist to reach for barrier $i$;

$\mathrm{X}$ - Barrier $i$ and $j$ will assist to reach each other;

$\mathrm{O}$ : Barriers $i$ and $j$ are not related to each other.

According to these symbols and inputs of experts, SSIM for the barriers in CSCM adoption was developed (See Table 4).

Table 4: SSIM for the barriers to CSCM implementation

\begin{tabular}{|c|c|c|c|c|c|c|c|c|c|c|c|c|c|c|c|c|}
\hline \multirow{2}{*}{$\begin{array}{l}\text { S. } \\
\text { No. }\end{array}$} & \multirow{2}{*}{$\begin{array}{l}\text { Barriers } \\
\text { to CSCM }\end{array}$} & \multicolumn{15}{|c|}{ Contextual Relations } \\
\hline & & B16 & B15 & B14 & B13 & B12 & B11 & B10 & B9 & B8 & B7 & B6 & B5 & B4 & $\mathbf{B 3}$ & B2 \\
\hline 1 & B1 & $\mathrm{V}$ & $\mathrm{V}$ & $\mathrm{V}$ & $\mathrm{V}$ & $\mathrm{V}$ & $\mathrm{V}$ & $\mathrm{V}$ & $\mathrm{V}$ & $\mathrm{V}$ & $\mathrm{V}$ & $\mathrm{V}$ & $\mathrm{X}$ & $\mathrm{A}$ & $\mathrm{V}$ & $\mathrm{A}$ \\
\hline 2 & B2 & $\mathrm{O}$ & V & $\mathrm{V}$ & $\mathrm{V}$ & $\mathrm{V}$ & $\mathrm{V}$ & V & $\mathrm{V}$ & $\mathrm{V}$ & V & $\mathrm{V}$ & $\mathrm{V}$ & $\mathrm{X}$ & $\mathrm{V}$ & \\
\hline 3 & B3 & $\mathrm{V}$ & $\mathrm{V}$ & $\mathrm{V}$ & $\mathrm{V}$ & $\mathrm{V}$ & $\mathrm{V}$ & $\mathrm{V}$ & $\mathrm{V}$ & $\mathrm{V}$ & $\mathrm{V}$ & $\mathrm{V}$ & $\mathrm{A}$ & $\mathrm{A}$ & & \\
\hline 4 & B4 & $\mathrm{V}$ & $\mathrm{V}$ & $\mathrm{V}$ & $\mathrm{V}$ & $\mathrm{V}$ & $\mathrm{V}$ & $\mathrm{V}$ & $\mathrm{V}$ & $\mathrm{V}$ & $\mathrm{V}$ & $\mathrm{V}$ & $\mathrm{V}$ & & & \\
\hline 5 & B5 & $\mathrm{V}$ & $\mathrm{V}$ & $\mathrm{V}$ & $\mathrm{V}$ & $\mathrm{V}$ & $\mathrm{V}$ & $\mathrm{V}$ & $\mathrm{V}$ & $\mathrm{V}$ & $\mathrm{V}$ & $\mathrm{V}$ & & & & \\
\hline 6 & B6 & V & V & $\mathrm{V}$ & $\mathrm{V}$ & $X$ & $\mathrm{~V}$ & V & $\mathrm{V}$ & $\mathrm{V}$ & V & & & & & \\
\hline 7 & B7 & $\mathrm{V}$ & $X$ & $\mathrm{~V}$ & A & A & $\mathrm{V}$ & $X$ & $\mathrm{O}$ & $X$ & & & & & & \\
\hline 8 & B8 & $\mathrm{V}$ & $\mathrm{X}$ & $\mathrm{V}$ & $\mathrm{A}$ & $\mathrm{A}$ & $\mathrm{V}$ & $\mathrm{X}$ & $\mathrm{X}$ & & & & & & & \\
\hline 9 & B9 & $\mathrm{V}$ & $\mathrm{X}$ & $\mathrm{V}$ & $\mathrm{A}$ & $\mathrm{A}$ & $\mathrm{V}$ & $\mathrm{X}$ & & & & & & & & \\
\hline 10 & B10 & $\mathrm{V}$ & $\mathrm{X}$ & $\mathrm{V}$ & $\mathrm{A}$ & $\mathrm{A}$ & $\mathrm{V}$ & & & & & & & & & \\
\hline 11 & B11 & $\mathrm{V}$ & A & $X$ & $\mathrm{~A}$ & $\mathrm{~A}$ & & & & & & & & & & \\
\hline 12 & B12 & $\mathrm{V}$ & $\mathrm{V}$ & $\mathrm{V}$ & $\mathrm{V}$ & & & & & & & & & & & \\
\hline 13 & B13 & $\mathrm{V}$ & $\mathrm{V}$ & $\mathrm{V}$ & & & & & & & & & & & & \\
\hline 14 & B14 & $\mathrm{V}$ & $\bar{A}$ & & & & & & & & & & & & & \\
\hline 15 & B15 & V & & & & & & & & & & & & & & \\
\hline
\end{tabular}


Next task is to form the IRM. In this sense, we operated on SSIM and replaced the entries in SSIM with binary numbers (0 and 1$)$. This replacement was made on the basis of some logics, whose details are given as -:

- For every V in SSIM, we put ' 1 ' in $(i, j)$ entry and ' 0 ' in $(j, i)$ entry.

- For every A in SSIM, we put ' 0 ' in ( $i, j)$ entry and ' 1 ' in $(j, i)$ entry.

- For every X in SSIM, we put ' 1 ' in both $(i, j)$ and $(j, i)$ entries.

- For every O in SSIM, we put ' 0 ' in both $(i, j)$ and $(j, i)$ entries.

In the view of this, the IRM for the barriers to CSCM implementation is presented in Table 5.

Table 5: IRM for the barriers to CSCM implementation

\begin{tabular}{|c|c|c|c|c|c|c|c|c|c|c|c|c|c|c|c|c|c|}
\hline $\begin{array}{l}\text { S. } \\
\text { No. }\end{array}$ & $\begin{array}{l}\text { Barriers to } \\
\text { CSCM }\end{array}$ & B1 & B2 & B3 & B4 & B5 & B6 & B7 & B8 & B9 & B10 & B11 & B12 & B13 & B14 & B15 & B16 \\
\hline 1 & B1 & 1 & 0 & 1 & 0 & 1 & 1 & 1 & 1 & 1 & 1 & 1 & 1 & 1 & 1 & 1 & 1 \\
\hline 2 & B2 & 1 & 1 & 1 & 1 & 1 & 1 & 1 & 1 & 1 & 1 & 1 & 1 & 1 & 1 & 1 & 0 \\
\hline 3 & B3 & 0 & 0 & 1 & 0 & 0 & 1 & 1 & 1 & 1 & 1 & 1 & 1 & 1 & 1 & 1 & 1 \\
\hline 4 & B4 & 1 & 1 & 1 & 1 & 1 & 1 & 1 & 1 & 1 & 1 & 1 & 1 & 1 & 1 & 1 & 1 \\
\hline 5 & B5 & 1 & 0 & 1 & 0 & 1 & 1 & 1 & 1 & 1 & 1 & 1 & 1 & 1 & 1 & 1 & 1 \\
\hline 6 & B6 & 0 & 0 & 0 & 0 & 0 & 1 & 1 & 1 & 1 & 1 & 1 & 1 & 1 & 1 & 1 & 1 \\
\hline 7 & B7 & 0 & 0 & 0 & 0 & 0 & 0 & 1 & 1 & 0 & 1 & 1 & 0 & 0 & 1 & 1 & 1 \\
\hline 8 & B8 & 0 & 0 & 0 & 0 & 0 & 0 & 1 & 1 & 1 & 1 & 1 & 0 & 0 & 1 & 1 & 1 \\
\hline 9 & B9 & 0 & 0 & 0 & 0 & 0 & 0 & 0 & 1 & 1 & 1 & 1 & 0 & 0 & 1 & 1 & 1 \\
\hline 10 & B10 & 0 & 0 & 0 & 0 & 0 & 0 & 1 & 1 & 1 & 1 & 1 & 0 & 0 & 1 & 1 & 1 \\
\hline 11 & B11 & 0 & 0 & 0 & 0 & 0 & 0 & 0 & 0 & 0 & 0 & 1 & 0 & 0 & 1 & 0 & 1 \\
\hline 12 & B12 & 0 & 0 & 0 & 0 & 0 & 1 & 1 & 1 & 1 & 1 & 1 & 1 & 1 & 1 & 1 & 1 \\
\hline 13 & B13 & 0 & 0 & 0 & 0 & 0 & 0 & 1 & 1 & 1 & 1 & 1 & 0 & 1 & 1 & 1 & 1 \\
\hline 14 & B14 & 0 & 0 & 0 & 0 & 0 & 0 & 0 & 0 & 0 & 0 & 1 & 0 & 0 & 1 & 0 & 1 \\
\hline 15 & B15 & 0 & 0 & 0 & 0 & 0 & 0 & 1 & 1 & 1 & 1 & 1 & 0 & 0 & 1 & 1 & 1 \\
\hline 16 & B16 & 0 & 0 & 0 & 0 & 0 & 0 & 0 & 0 & 0 & 0 & 0 & 0 & 0 & 0 & 0 & 1 \\
\hline
\end{tabular}

Next, we transform the IRM into FRM by applying transitivity rule as explained in Section 3. Table 6 shows the obtained FRM for the barriers to CSCM implementation. Next, the driving and dependence power was derived by summing the rows and column entries in the FRM. 
Table 6: FRM for the barriers to CSCM implementation

\begin{tabular}{|c|c|c|c|c|c|c|c|c|c|c|c|c|c|c|c|c|c|c|}
\hline $\begin{array}{l}\text { S. } \\
\text { No. }\end{array}$ & $\begin{array}{l}\text { Barriers } \\
\text { to CSCM }\end{array}$ & B1 & B2 & B3 & B4 & B5 & B6 & B7 & B8 & B9 & B10 & B11 & B12 & B13 & B14 & B15 & B16 & $\begin{array}{l}\text { Driving } \\
\text { Power }\end{array}$ \\
\hline 1 & B1 & 1 & 0 & 1 & 0 & 1 & 1 & 1 & 1 & 1 & 1 & 1 & 1 & 1 & 1 & 1 & 1 & 14 \\
\hline 2 & B2 & 1 & 1 & 1 & 1 & 1 & 1 & 1 & 1 & 1 & 1 & 1 & 1 & 1 & 1 & 1 & $1 *$ & 16 \\
\hline 3 & B3 & 0 & 0 & 1 & 0 & 0 & 1 & 1 & 1 & 1 & 1 & 1 & 1 & 1 & 1 & 1 & 1 & 12 \\
\hline 4 & B4 & 1 & 1 & 1 & 1 & 1 & 1 & 1 & 1 & 1 & 1 & 1 & 1 & 1 & 1 & 1 & 1 & 16 \\
\hline 5 & B5 & 1 & 0 & 1 & 0 & 1 & 1 & 1 & 1 & 1 & 1 & 1 & 1 & 1 & 1 & 1 & 1 & 14 \\
\hline 6 & B6 & 0 & 0 & 0 & 0 & 0 & 1 & 1 & 1 & 1 & 1 & 1 & 1 & 1 & 1 & 1 & 1 & 11 \\
\hline 7 & B7 & 0 & 0 & 0 & 0 & 0 & 0 & 1 & 1 & $1 *$ & 1 & 1 & 0 & 0 & 1 & 1 & 1 & 8 \\
\hline 8 & B8 & 0 & 0 & 0 & 0 & 0 & 0 & 1 & 1 & 1 & 1 & 1 & 0 & 0 & 1 & 1 & 1 & 8 \\
\hline 9 & B9 & 0 & 0 & 0 & 0 & 0 & 0 & $1 *$ & 1 & 1 & 1 & 1 & 0 & 0 & 1 & 1 & 1 & 8 \\
\hline 10 & B10 & 0 & 0 & 0 & 0 & 0 & 0 & 1 & 1 & 1 & 1 & 1 & 0 & 0 & 1 & 1 & 1 & 8 \\
\hline 11 & B11 & 0 & 0 & 0 & 0 & 0 & 0 & 0 & 0 & 0 & 0 & 1 & 0 & 0 & 1 & 0 & 1 & 3 \\
\hline 12 & B12 & 0 & 0 & 0 & 0 & 0 & 1 & 1 & 1 & 1 & 1 & 1 & 1 & 1 & 1 & 1 & 1 & 11 \\
\hline 13 & B13 & 0 & 0 & 0 & 0 & 0 & 0 & 1 & 1 & 1 & 1 & 1 & 0 & 1 & 1 & 1 & 1 & 9 \\
\hline 14 & B14 & 0 & 0 & 0 & 0 & 0 & 0 & 0 & 0 & 0 & 0 & 1 & 0 & 0 & 1 & 0 & 1 & 3 \\
\hline 15 & B15 & 0 & 0 & 0 & 0 & 0 & 0 & 1 & 1 & 1 & 1 & 1 & 0 & 0 & 1 & 1 & 1 & 8 \\
\hline 16 & B16 & 0 & 0 & 0 & 0 & 0 & 0 & 0 & 0 & 0 & 0 & 0 & 0 & 0 & 0 & 0 & 1 & 1 \\
\hline \multicolumn{2}{|c|}{$\begin{array}{l}\text { Dependence } \\
\text { Power }\end{array}$} & 4 & 2 & 5 & 2 & 4 & 7 & 13 & 13 & 13 & 13 & 15 & 7 & 8 & 15 & 13 & 16 & 150 \\
\hline
\end{tabular}

After FRM, we partitioned the barriers into various levels to know their prominence or importance levels in the hierarchy of barriers. For this, we used the reachability matrix, and correspondingly formed both the reachability set and antecedent set. In the reachability set, we clustered the barrier itself and the other barriers affected by that barrier. In the antecedent set, we combined the barrier itself and other barriers that affect this barrier. Further, we combined the reachability set and antecedent set and the intersection set was formed. This procedure is repeated for all the barriers. Notably, we have to assign Level 1 to that barrier for which the reachability and intersection set are identical. For example, 'Lack of economic benefits in short-run (16)' assigned level 1. Once the level is assigned to the barrier, then that barrier is eliminated. This procedure is repeated to assign at most one level to each barrier. Various iterations involved in developing of ISM based model of the barriers in CSCM implementation are provided in Annexure-1 and final levels for the barriers are depicted in Table 7. 
Table 7: Final levels for the barriers to CSCM implementation

\begin{tabular}{|c|c|c|}
\hline $\begin{array}{l}\text { S. } \\
\text { No. }\end{array}$ & $\begin{array}{l}\text { Level } \\
\text { number }\end{array}$ & Barriers in CSCM implementation \\
\hline 1 & $1^{\text {st }}$ & - $\quad$ Lack of economic benefits in short-run (B16) \\
\hline 2 & $2^{\text {nd }}$ & $\begin{array}{l}\text { - Lack of appropriate training and development programs for SC members and HR } \\
\text { (B11) } \\
\text { - Lack of coordination and collaboration among SC members (B14) }\end{array}$ \\
\hline 3 & $3^{\text {rd }}$ & 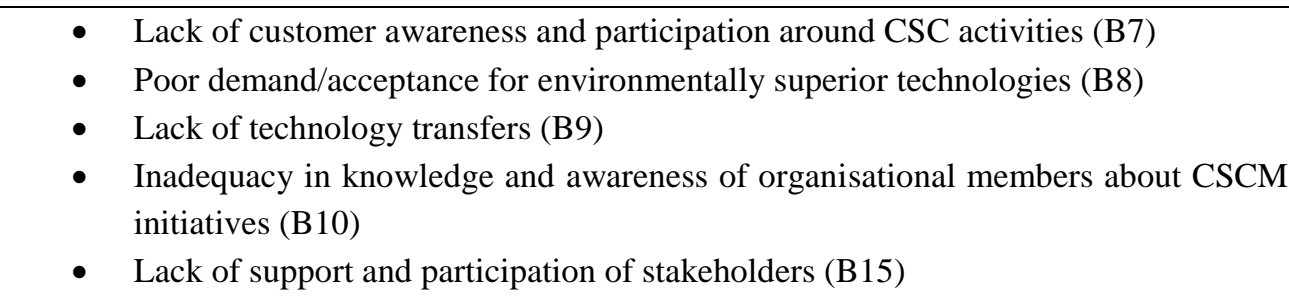 \\
\hline 4 & $4^{\text {th }}$ & - $\quad$ Lack of systematic information systems (B13) \\
\hline 5 & $5^{\text {th }}$ & $\begin{array}{l}\text { - Lack of middle and lower level managers' support and involvement in promoting } \\
\text { 'greener' products (B6) } \\
\text { - } \quad \text { Lack of effective planning and management for CSCM concepts (B12) }\end{array}$ \\
\hline 6 & $6^{\text {th }}$ & - $\quad$ Lack of Management commitment and approach for CSSM adoption (B3) \\
\hline 7 & $7^{\text {th }}$ & 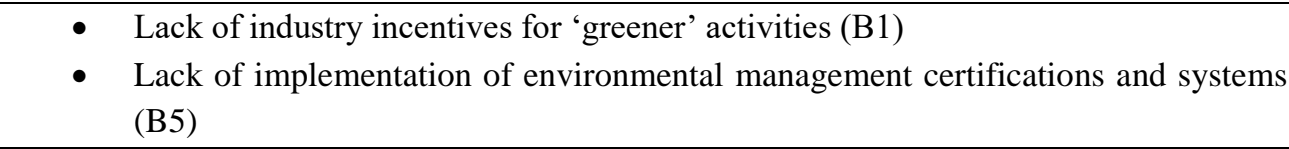 \\
\hline 8 & $8^{\text {th }}$ & $\begin{array}{ll}\text { - } & \text { Lack of environmental laws and regulations (B2) } \\
\text { - } & \text { Lack of preferential tax policies for promoting the circular models (B4) }\end{array}$ \\
\hline
\end{tabular}

After determining the levels of each barrier, the MICMAC analysis was conducted. According to this, the driving and dependence power of each barrier is analysed. For determining the driving and dependence power, the FRM is used and summation of rows and columns was calculated. The summation of rows and columns provides the driving and dependence powers for each barrier respectively (see Table 6). Based on MICMAC analysis, the barriers were analysed to have further insights on the sources and consequences of the problematic issues in extending circular models in industrial supply chains. The MICMAC analysis diagram illustrating the driver and dependence power is shown in Figure 3. 


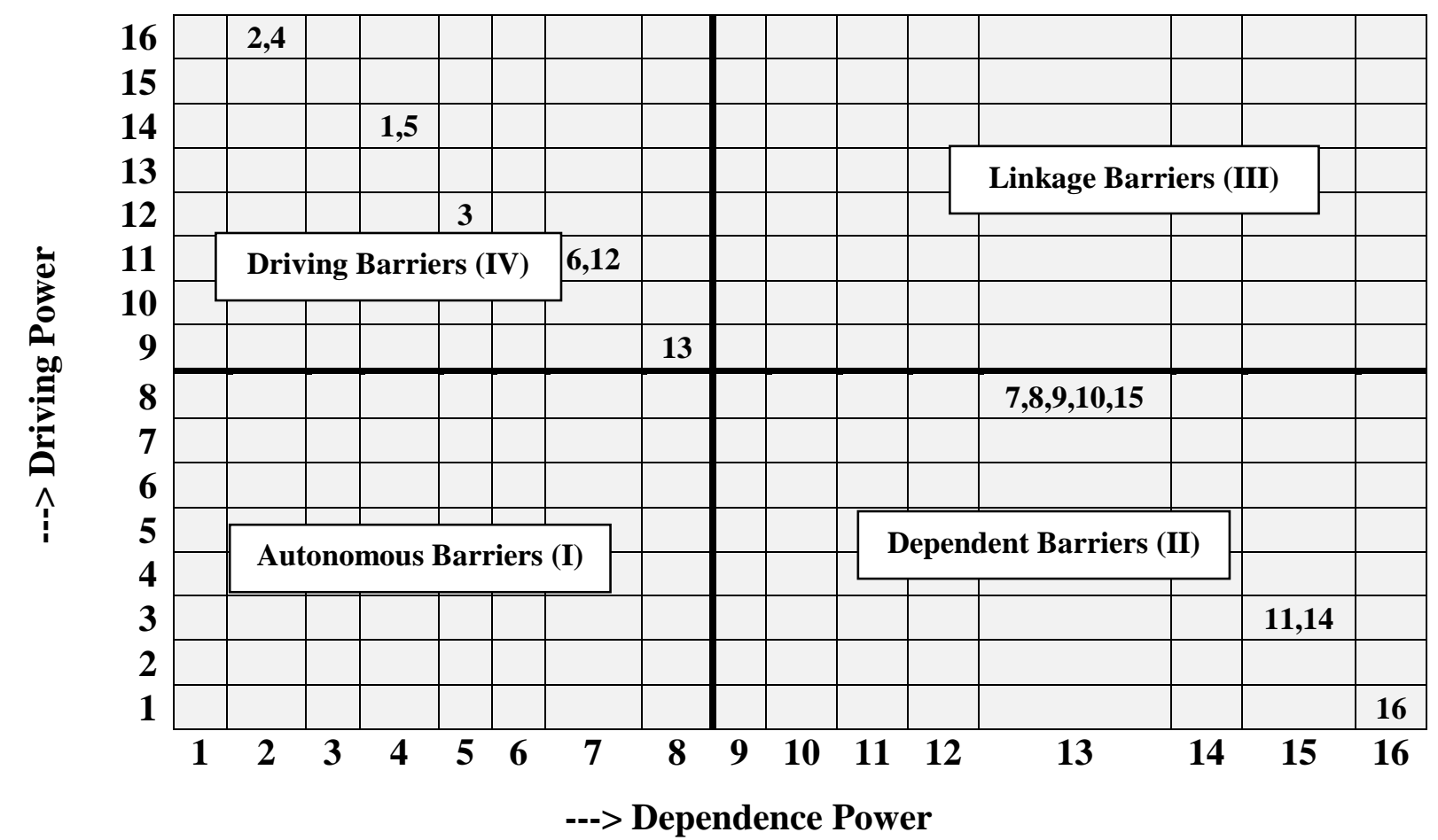

Figure 3: MICMAC analysis for the barriers to CSCM implementation

The identified sixteen barriers are divided into four categories (see Figure 3), described as below,

1. Autonomous: These barriers consist of weak driving power, weak dependence power (lower left quadrant) and relatively disconnected from the system. No barrier falls in this category. Therefore, among the identified sixteen barriers, all the barriers have a lot of influence in the CSCM implementation.

2. Dependent: These barriers consist of weak driving power and strong dependence power (lower right quadrant); and coming top of ISM based hierarchical model. Eight barriers namely lack of economic benefits in short-run (16); lack of appropriate training and development programs for supply chain members and HR (11); lack of coordination and collaboration among SC members (14); lack of customer awareness and participation around CSC activities (7); poor demand/acceptance for environmentally superior technologies (8); lack of technology transfers (9); inadequacy in knowledge and awareness of organisational members about CSCM practices (10); and lack of support and participation of stake holders (15) have been categorized as dependent barriers. These barriers should be regarded as the important barriers because their strong dependence points out that they need removal of all the other barriers to adopt CSCM concepts.

3. Linkage: These barriers consist of strong driving power and strong dependence power (upper right quadrant); and coming middle of ISM based hierarchical model. No barrier 
falls in this category. These barriers are unstable hence required careful analysis and practitioners should continuously observe these barriers at each stage of implementation.

4. Drivers: These barriers consists of strong driving power and weak dependence power (upper left quadrant); and coming bottom of ISM based hierarchical model. Eight barriers i.e. lack of systematic information systems (13); lack of middle and lower level managers' support and involvement in promoting 'greener' products (6); lack of effective planning and management of circular supply chain concepts (12); lack of Management commitment and approach for CSCM adoption (3); lack of industry incentives for 'greener' activities (1); lack of implementation of environmental management certifications and systems (5); lack of environmental laws and regulations (2); and lack of preferential tax policies for a unified platform for promoting the circular models (4) have been categorized as the driving barriers in our study. Business organisations need to concentrate on these barriers more carefully and might be treated as the root cause of all the other barriers. It has been observed that these barriers may help to removal of other barriers, appearing at the middle and top of ISM based hierarchy framework. Barriers having higher driving power require to be taken care on the priority basis because there are some other dependent barriers being influenced by them.

After MICMAC analysis, we developed both the digraph and ISM model. FRM assist us in developing the structured ISM model through vertices/nodes and lines of edges. The structural model of barriers in CSCM adoption developed using the FRM is termed as a digraph (see Figure 4). 


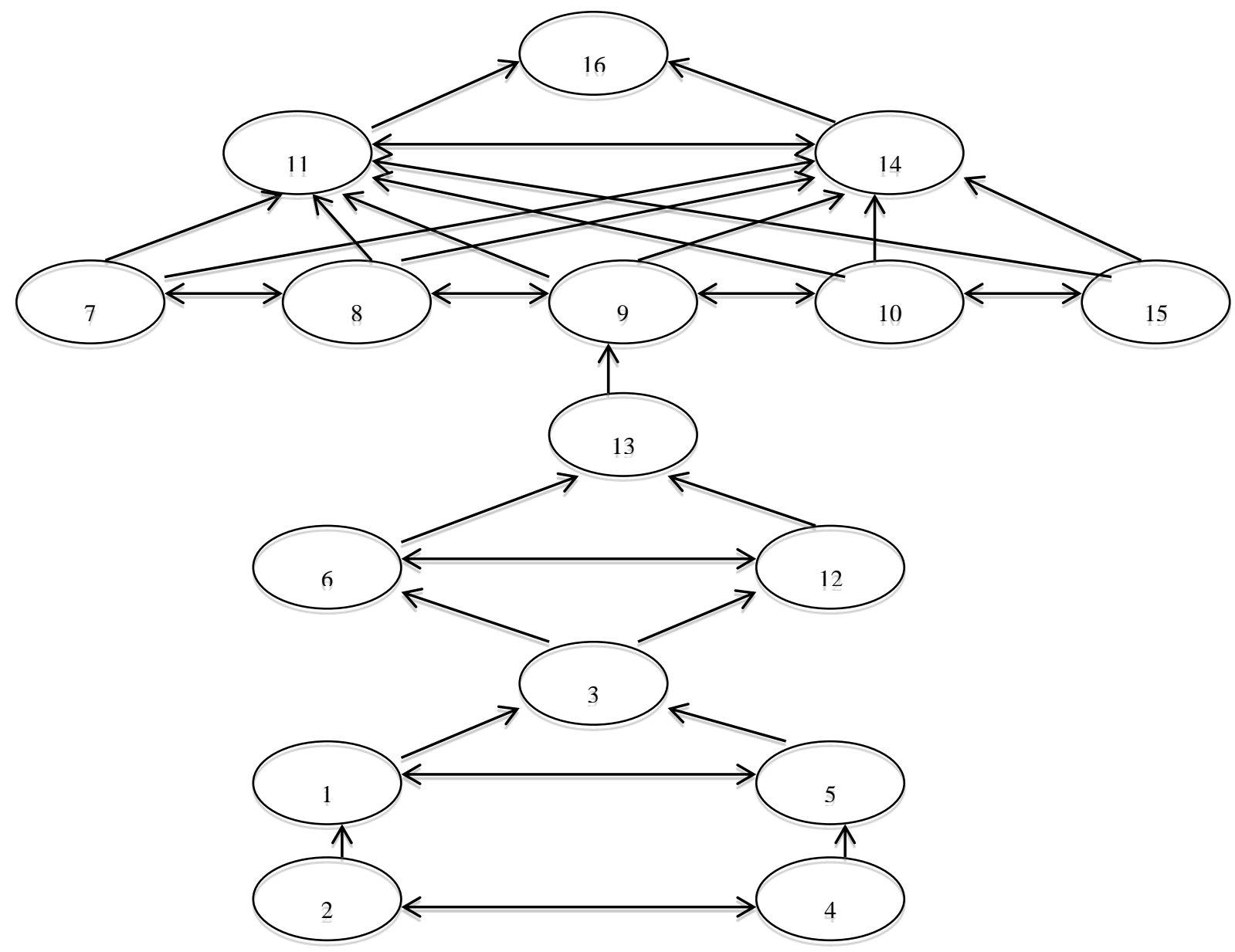

Figure 4: Digraph for the barriers to CSCM implementation

Next, the developed digraph was transformed into ISM based hierarchical model. This transformation was done by removing transitivity links and putting assigned barriers on the place of their nodes. In this way, the ISM based hierarchical model for the barriers was developed (see Figure 5). The suggested ISM based model illustrates the contribution of the barriers 'lack of environmental laws and regulations (B2)' and 'lack of preferential tax policies for promoting the circular models (B4)' which forms the foundation of the hierarchical structure in CSCM implementation. The ISM based model shows an interaction of various barriers in terms of their significance approaching towards the upmost level 1 ('lack of economic benefits in short-run (16)') from level 8 ('lack of environmental laws and regulations (B2)' and 'lack of preferential tax policies for promoting the circular models (B4)'). From model, it can be concluded that a barrier placed at a definite level will not aid to accomplish any other barrier placed at the level above of that. 


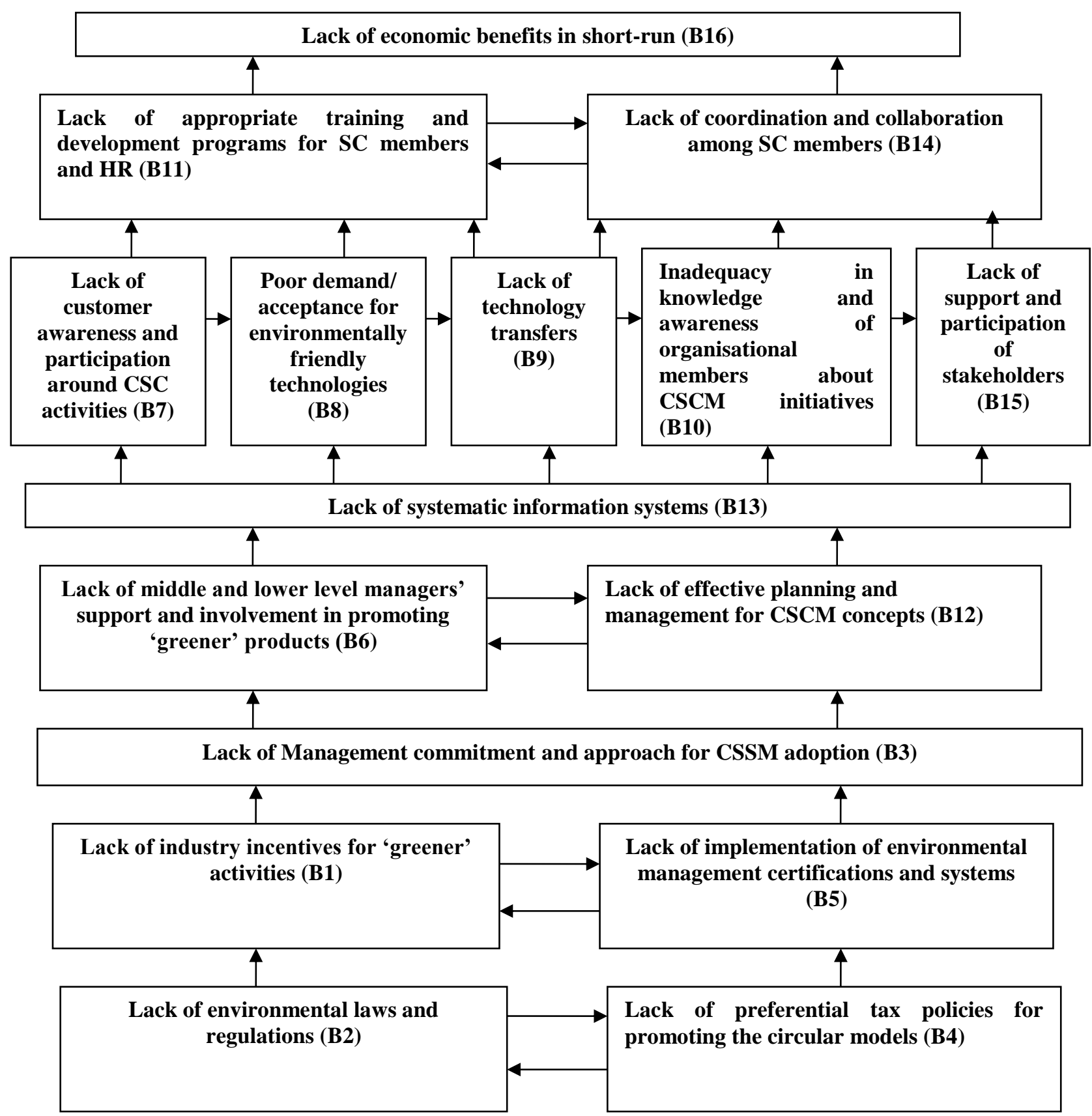

Figure 5: ISM based hierarchical model for the barriers to CSCM implementation

The barriers 'B2' and 'B4' impede the implementation of CSCM concepts among automotive business organisations in India. These two barriers will also affect each other bilaterally and act as key barriers to CSCM adoption. Luthra et al., (2015a) suggested that lack of regulations and policies is still the main challenge in India to promote innovative green/sustainable practices in supply chain. The barriers related to environmental laws and regulations and favoured tax schemes for promoting the CSC models would leads to 'lack of industry incentives for 'greener' activities (B1)' and 'lack of implementation of 
environmental management certifications and systems (B5)' in the automotive industry supply chain, which will lead to 'lack of Management commitment and approach for CSSM adoption (B3)'. Pan et al., (2013) highlighted that even when environmental regulations are well drafted and jurisdictional mandates are clear, implementation and enforcement often remain weak or absent when requirements target economically important activities. Su et al., (2013) suggested that most of business organisations insufficient incentives to accept "greener activities" to reduce waste reduction, as up gradation of equipment and technology needs more money and management patience to maximize their economic gains. Lack of management commitment and approach for CSSM adoption will lead to 'lack of middle and lower level managers' support and involvement in promoting 'greener' products (B6)' and 'lack of effective planning and management CSCM concepts (B12)'. Notably, the barriers related to lack of management commitment will include organisation' strategy, planning, involvement, hiring and training personnel and eagerness, to learn best practices in CSSM adoption. These barriers will lead to 'lack of systematic information systems (B13)' to implement CSCM practices.

Lack of systematic information systems will impede 'lack of customer awareness and participation around CSC activities (B7)', 'poor demand/ acceptance for environmentally friendly technologies (B8)', 'lack of technology transfers (B9)', 'inadequacy in knowledge and awareness of organisational members about CSCM initiatives (B10)' and 'lack of support and participation of stakeholders (B15)'. These barriers will affect 'lack of appropriate training and development programs for SC members and HR (B11)' and 'lack of coordination and collaboration among SC members (B14)' in two-way direction to each other and impeding to implement CSCM concepts. These two barriers collectively lead to barriers related to the 'lack of economic benefits in short-run (B16)'. It has been suggested that adoption of greener and sustainable activities are strategic decisions and usually provide economic benefits at the strategic level (Mangla et al., 2014). In fact, there is still a lack of model based research on the environmental, economic and employment effects of the CSC initiatives in automotive supply chain sector in India (Horbach et al., 2015).

\section{Policy Recommendation and Implication for Implementing CSCM in India}

In this section, several policy recommendation and implications for implementing CSCM in context of India are provided. CSCM enhance the circular flow of products, by-products and waste generated by integrating the practices of reuse, recycling and remanufacturing into their supply chains (Ellen Mac Arthur Foundation, 2014). This leads to incredible savings in 
terms of resources, finances and has a potential to generate plenty of employment opportunities. However, in developing economy, such as India, the lack of government assistance in terms of funding options, efficient taxation norms, and import duty is a crucial challenge for the promotion of green investments (Geng and Doberstein, 2008; Prendeville et al., 2016). During the study, it was found that the absence of firm legislative mechanism also affects the manufacturing firm's decisions to incorporate eco-friendly solution to their operations. A strategic regulatory framework with specific resource consumption targets needs to be developed for design and implementation of environment friendly policies (Mangla et al., 2014). Novel legislative norms should be framed for easing competitiveness concerns and lowering the CSCM adoption expenses. The subsidies promoting disproportionate exploitation of resources and similar frictions to achieve green manufacturing operations should be abandoned. A comprehensive policy on government owned procurement and material handling processes can further help to implement the circular supply models. They can generate monetary stimuli by underwriting certain threats (failures, increase in cost) related to green innovative businesses. Usually, the upfront expenses and the anticipated payback period are crucial in CSCM adoption.

The emerging economy, such as India is also more sensitive to additional overheads due to eco-friendly activities as compared to the advanced economy. There are also hidden expenditures in terms of time and labour, which businesses have to devote to accomplish low carbon operations (Zhu and Geng, 2013). Creating new resources via public funds might be troublesome in India because of their economic scenario. An array of already existing low carbon funding provisions can enhance the transformative operations towards CSCM. Multilateral development banks could aim for supplementary boost for CSCM investments. Government could ease the foreign direct investment in the domain of CSCM and encourage research for CSCM implementation by providing subsidies and tax credit initiatives (Gupta and Palsule-Desai, 2011). They should establish market based initiatives in terms of redesigning products to boost and encourage sustainable investments. It will result in innovative design to lower carbon footprint and costs to consumers as well as develop system and business model to deliver the optimum monetary and eco-friendly loops within operation of CSCM. Businesses need to follow a proactive approach in efficiently addressing their waste streams and raising awareness that reducing waste leads to significant savings (Nasir et al., 2017).

Indian government should develop a national strategy for efficient alignment of rising number and diverse skillset of people in the circular manufacturing ecosystem. The policy 
makers should take appropriate steps for increasing the number of skilled labour, managers by introducing novel training facilities, apprenticeship schemes and degree programs with in depth knowledge of circular manufacturing operations (Lacy and Rutqvist, 2015). In developed countries, there is a significant heterogeneity among the manufacturing industries across various domains. Their capabilities and responses for implementing green operations are similar with respect to organisational and management regime. Management committee has the authority to make strategic transformations within the firm such as adopting the practices of CSCM. The extent to which management committee are willing to implement CSCM is usually depend on financial benefits (Zhu and Geng, 2013). The government should take appropriate measures to highlight the potential savings achieved by manufacturing firm by modifying their strategies from linear to circular. Lack of technical capability prevents Indian organisations from capitalising on green economy opportunities such as CSCM. They are trailing in identifying, evaluating and implementing modern infrastructure to lower carbon footprint and realise monetary savings. Development of smart infrastructure and tracking technology would encourage the reuse, recycling and remanufacturing of material and goods (Su et al., 2013). Development of technology in India should be aligned with nature of market in the present situation and predictable future.

One of the significant drivers of CSCM is quick access to information and visibility of the entire value chain for all the stakeholders (Pan et al., 2015). For instance, access to the real time data of generation of by-products at various manufacturing stages. Collaborative consumption and other similar business models needs to be established that capitalises on state of the art data driven applications for capturing data of whole supply chain. Robust strategies need to be modelled to track the value of resource flows, assisting manufacturing firms to identify the waste and carbon footprint generating processes. Lack of stakeholder's environmental awareness is a discouraging element for implementation of circular/green models in India (Luthra et al., 2015b). Suppliers are observed to be reluctant to foster a low carbon supply chains because of the potential overheads, which could jeopardize their competitiveness.

The SMEs particularly find the engagement of stakeholders challenging in eco-friendly operations due to their small size and limited bargaining power. These manufacturing firms could mitigate these issues by following an innovative approach in terms of collecting and exchanging information, devoting funds towards R\&D, disseminating good practices, promoting business to business collaboration. Restructuring in supply chains in India is required to facilitate information and products flow in both directions to integrate reuse, 
remanufacturing, reparability, durability in their production strategies. These milestones could be achieved by developing strong coordination in supply chains in terms of optimum communication, operation monitoring and information sharing (Defee et al., 2009).

The lack of awareness of the advantages of the CSCM hampers its adoption in emerging economy like India (Tukker, 2015). They consider resource efficient operations as an additional financial burden on their businesses. The government has to play active role in raising awareness regarding unlocking novel business opportunities from optimum waste management. Appropriate training should be given by multinational companies to SMEs for efficient re-use and recovery of waste products. The culture of repair and recycle needs to be promoted on a wider scale. All organisational members should be provided access to funding and risk management tools to boost investment in CSCM initiatives. There is a considerable amount of waste generated at consumer level, which is not being reused or recycled in developing nations. Consumers' awareness needs to be increased for accomplishing green operations like CSCM.

Manufacturing firms could act as an enabler for CSCM and develop life term service relationship with consumers instead of one-time transaction to implement circular solutions in the supply chain (Ceschin, 2013). Appropriate end of life treatment should be provided to consumer products. Rental or leasing schemes could be launched for accumulating customer insights for advanced personalisation and customisation. A collaborative consumption model needs to be developed for improved interaction among customers, suppliers and retailers to generate innovative service to customers that emphasise 'access of products' rather than 'owner of products.'

The transition to CSCM practices needs to be accelerated within a time frame consistent with response to major environmental issues such as global warming, water scarcity etc. Resource productivity could be taken at next level by complementing deployment of modern technology with structural reforms within the industry. The economics of recovery, reuse, remanufacture would be transformed by effective incentivising to promote strategic planning of the whole supply chain from manufacturer to consumer. Their strategies must be aligned to boost the circular pattern of resource flows such as switching to durable goods, resource efficient designing, reuse of intermediate products, modularization and remanufacturing. 


\section{Concluding Remarks, Limitations and Future Work}

Due to increased ecological awareness and need to address unsustainable patterns of resource consumption and waste production, business organisations all across the globe are seeking to extend circular models into their supply chains. The extension of circular models or CSC concepts allows organisations to have efficient use of resources and results in enhanced value to the customer. At the same time, it has also been seen that the adoption of CSCM is difficult for the organisations, especially in developing nations such as India due to the existence of various constraints related to finance, government regulations etc.

In the view of this, this contribution is an effort to distinguish and analyse significant barriers to adopt CSCM concepts by taking an Indian perspective. In this research, we distinguish 16 barriers related to CSCM adoption using the literature survey and feedback received from the experts. The prime purpose of this study is to know the contextual relations between various identified barriers and develop a hierarchy of barriers in CSCM implementation in Indian context. Generally, managers' focus on one or more barriers as being crucial in increasing CSCM success rate effectiveness, however, due to presence of interactive relations, one barrier may significantly affect the other barriers in CSCM adoption. To achieve this, an integrated approach based on ISM and MICMAC was used in this work.

According to the findings, the barriers ' lack of environmental laws and regulations (B2)' and 'lack of preferential tax policies for promoting the circular models (B4)' form the foundation (higher effectiveness) of the ISM hierarchical structure in CSCM implementation from the Indian context.

The present work has some limitations and future research directions as well. This research suggests an integrated ISM-MICMAC based analysis framework as per experts' feedback. The developed ISM based framework grounds on expert's judgements, which needs to be carried out very carefully. This work suggests 16 barriers in relation to implementation of CSCM initiatives in the supply chain. The identification of the barriers could be further explored. The integrated ISM-MICMAC based analysis is also not capable of illustrating the interpretive logic of dominance/interaction among barriers to CSCM. Thus, to develop an interpretive logic of all the interactions involved in ISM model, total interpretive structural modelling (TISM) may be utilized in the future. For empirically testing and validating the framework and ISM based results of this study, we may apply Structural Equation Modelling (SEM) or Systems Dynamics Modelling (SDM), which are kept out of scope in the present work. In future, fuzzy approach may also be mixed into ISM to capture any unclearness in data. The identified barriers may be further evaluated using DEMATEL, AHP, ANP and 
results can be compared. The social challenges that CE/CSC could address may also be explored in future studies. The developed framework is applied to Indian context; we may apply the framework in other developing countries and results may be compared in future studies. This also enables to have more intense theoretical contributions in the domain of CSCM adoption. To the end, the findings presented in this study will help Indian managers and government bodies to address the issues related to economic prosperity and climate change by focusing on the circular supply chains models in business.

\section{Acknowledgement}

The authors would like to thank the project 'A cross country examination of supply chain barriers on market access for small and medium firms in India and UK' (Ref no: PM130233) funded by British Academy, UK for supporting this research.

\section{References}

Agarwal, A., R. Shankar, and M. K. Tiwari. 2007. "Modelling Agility of Supply Chain." Industrial Marketing Management 36 (4): 443-457.

Agi, M. A., and R. Nishant. 2017. "Understanding Influential Factors on Implementing Green Supply Chain Management Practices: An Interpretive Structural Modelling Analysis." Journal of Environmental Management 188: 351-363.

Ashton, W., and M. Shenoy. 2015. Industrial Ecology in India: Converging Traditional Practice and Modern Environmental Protection. International Perspectives on Industrial Ecology, Cheltenham, UK and Northampton, MA, USA: Edward Elgar: 12-29.

Baines, T. S. 1994. Modelling in the Evaluation of A Manufacturing Strategy. Ph. D. thesis, Cranfield University, Cranfield.

Benton, D., J. Hazell, and J. Hill. 2015. The Guide to the Circular Economy: Capturing Value and Managing Material Risk. Greenleaf Publishing Co. ISBN: 978-1910174357

Boulding, K. 1966. The Economy of the Coming Spaceship Earth. In: Daly, H., Freeman, W.H. (Eds.), (1980). Economics, Ecology, Ethics: Essay towards a Steady State Economy. San Francisco.

Ceschin, F. 2013. Sustainable Product-Service Systems: Between Strategic Design and Transition Studies. Springer Science \& Business Media, U.K..

Checkland, P. B. and J. Scholes. 1999. Soft Systems Methodology In Action. John Wiley and Sons, Chichester, England. 
Defee, D. C., T. Esper, and D. Mollenkopf. 2009. "Leveraging Closed-Loop Orientation and Leadership for Environmental Sustainability." Supply Chain Management: An International Journal 14 (2): 87-98.

del Brio, A. J., B. Junquera, and M. Ordiz. 2008. "Human Resources in Advanced Environmental Approaches-A Case Analysis." International Journal of Production Research 46 (21): 6029-6053.

Diabat, A., A. Khreishah, G. Kannan, V. Panikar, and A. Gunasekaran. 2013. "Benchmarking the Interactions Among Barriers in Third-Party Logistics Implementation: An ISM Approach.” Benchmarking: An International Journal 20 (6): 805-824.

Dora, M., M. S. Bhatia, and D. Gallear. 2016. "Supply Chain in a Circular Economy: A Multidimensional Research Agenda." Online Available at: http://bura.brunel.ac.uk/handle/ $\underline{2438 / 13002}$

Ellen MacArthur Foundation. 2014. Towards the Circular Economy. In: Accelerating the ScaleUp across Global Supply Chains 3: 1-99.

Esfahbodi, A., Y. Zhang, and G. Watson. 2016. "Sustainable Supply Chain Management in Emerging Economies: Trade-offs Between Environmental and Cost Performance." International Journal of Production Economics 181: 350-366.

Gallaud, D., and B. Laperche. 2016. Circular Economy, Industrial Ecology and Short Supply Chain: Towards Sustainable Territories. John Wiley \& Sons, New Jersey.

Geng, Y., and B. Doberstein. 2008. "Developing the Circular Economy in China: Challenges and Opportunities for Achieving' Leapfrog Development." The International Journal of Sustainable Development \& World Ecology 15 (3): 231-239.

Geng, Y., J. Fu, J. Sarkis, and B. Xue. 2012. “Towards A National Circular Economy Indicator System in China: An Evaluation and Critical Analysis.” Journal of Cleaner Production 23 (1): 216-224.

Geng, Y., Q. Zhu, B. Doberstein, and T. Fujita. 2009. “Implementing China's Circular Economy Concept at the Regional Level: A Review of Progress in Dalian, China." Waste Management 29 (2): 996-1002.

Genovese, A., A. A. Acquaye, A. Figueroa, A., and S. L. Koh. 2017. "Sustainable Supply Chain Management and The Transition towards A Circular Economy: Evidence and Some Applications." Omega 66: 344-357.

George, D. A., B. C. A. Lin, and Y. Chen. 2015. "A Circular Economy Model of Economic Growth." Environmental Modelling \& Software 73: 60-63. 
Ghisellini, P., C. Cialani, and S. Ulgiati. 2016. "A Review on Circular Economy: The Expected Transition to a Balanced Interplay of Environmental and Economic Systems." Journal of Cleaner Production 114: 11-32.

Ghosh, S. K. 2016. "Global Circular Economy and Waste Management.” Journal of Solid Waste Technology \& Management 73 (1): 1-14.

Giunipero, L. C., R. E. Hooker, and D. Denslow. 2012. "Purchasing and Supply Management Sustainability: Drivers and Barriers." Journal of Purchasing and Supply Management 18 (4): $258-269$.

Glock, C. H., E. H. Grosse, and J. M. Ries. 2014. "The Lot Sizing Problem: A Tertiary Study." International Journal of Production Economics 155: 39-51.

Glock, C. H., E. H. Grosse, and J.M. Ries. 2016. Decision support models for supplier development: systematic literature review and research agenda (No. 77945). Darmstadt Technical University, Department of Business Administration, Economics and Law, Institute for Business Studies (BWL).

Govindan, K., H. Soleimani, and D. Kannan. 2015. "Reverse Logistics and Closed-Loop Supply Chain: A Comprehensive Review to Explore the Future.” European Journal of Operational Research 240 (3): 603-626.

Goyal, S., M. Esposito, and A. Kapoor. 2016. "Circular Economy Business Models in Developing Economies: Lessons from India on Reduce, Recycle, and Reuse Paradigms.” Thunderbird International Business Review, DOI: 10.1002/tie.21883

Guerrero-Baena, M. D., J. A. Gómez-Limón, and J.V. Fruet. 2015. “A Multi-Criteria Method for Environmental Management System Selection: An Intellectual Capital Approach.” Journal of Cleaner Production 105: 428-437.

Gunasekaran, A., Z. Irani, K. L. Choy, L. Filippi, and T. Papadopoulos. 2015. "Performance Measures and Metrics in Outsourcing Decisions: A Review for Research and Applications." International Journal of Production Economics 161: 153-166.

Gupta, S., and O. D. Palsule-Desai. 2011. "Sustainable Supply Chain Management: Review and Research Opportunities.” IIMB Management Review 23 (4): 234-245.

Haleem, A., S. Luthra, B. Mannan, S. Khurana, S. Kumar, and S. Ahmad. 2016. "Critical Factors for the Successful Usage of Fly Ash in Roads \& Bridges and Embankments: Analysing Indian Perspective." Resources Policy 49: 334-348.

Horbach, J., K. Rennings, and K. Sommerfeld. 2015. Circular economy and employment. Available at: https://www.sun-institute.org/wc/files/ce_employment_13052015.pdf 
Jakhar, S. K., and M. K. Barua. 2014. "An Integrated Model of Supply Chain Performance Evaluation and Decision-Making Using Structural Equation Modelling and Fuzzy AHP." Production Planning \& Control 25 (11): 938-957.

Kaushik, A., S. Kumar, S. Luthra, and A. Haleem. 2014. "Technology Transfer: Enablers and Barriers-A Review.” International Journal of Technology, Policy and Management 14 (2): $133-159$.

Kumar, R., and R. Chandrakar. 2012. "Overview of Green Supply Chain Management: Operation and Environmental Impact at Different Stages of the Supply Chain.” International Journal of Engineering and Advanced Technology 1 (3): 1-6.

Kumar, S., and P. Malegeant. 2006. "Strategic Alliance in A Closed-Loop Supply Chain, A Case of Manufacturer and Eco-Non-Profit Organization.” Technovation 26 (10): 1127-1135.

Kumar, S., S. Luthra, K. Govindan, N. Kumar and A. Haleem. 2016. "Barriers in Green Lean Six Sigma Product Development Process: An ISM Approach.” Production Planning \& Control, 27 (7-8): 604-620.

Lacy, P., and J. Rutqvist. 2015. Five Circular Capabilities for Driving Value. In Waste to Wealth (pp. 148-167). Palgrave Macmillan, UK.

Li, J., S. Y. Pan, H. Kim, J. H. Linn, and P. C. Chiang. 2015. "Building Green Supply Chains in Eco-Industrial Parks towards A Green Economy: Barriers and Strategies.” Journal of Environmental Management 162: 158-170.

Lieder, M., and A. Rashid. 2016. "Towards Circular Economy Implementation: A Comprehensive Review in Context of Manufacturing Industry." Journal of Cleaner Production 115: 36-51.

Loomba, A. P., and K. Nakashima. 2012. "Enhancing Value in Reverse Supply Chains by Sorting Before Product Recovery." Production Planning \& Control 23 (2-3): 205-215.

Low, J. S. C., T. B. Tjandra, W. F. Lu, and H. M. Lee. 2016. "Adaptation of the Product Structure-based Integrated Life cycle Analysis (PSILA) Technique for Carbon Footprint Modelling and Analysis of Closed-Loop Production Systems." Journal of Cleaner Production 120: 105-123.

Luthra, S., D. Garg, and A. Haleem. 2015a. "An Analysis of Interactions among Critical Success Factors to Implement Green Supply Chain Management towards Sustainability: An Indian Perspective." Resources Policy 46: 37-50.

Luthra, S., D. Garg, and A. Haleem. 2015b. "Critical Success Factors of Green Supply Chain Management for achieving Sustainability in Indian Automobile Industry." Production Planning \& Control 26 (5): 339-362. 
Luthra, S., K. Govindan, D. Kannan, S. K. Mangla, and C. P. Garg. 2017. "An Integrated Framework for Sustainable Supplier Selection and Evaluation in Supply Chains.” Journal of Cleaner Production 140: 1686-1698.

Luthra, S., V. Kumar, S. Kumar, and A. Haleem. 2011. "Barriers to Implement Green Supply Chain Management in Automobile Industry Using Interpretive Structural Modeling Technique: An Indian Perspective.” Journal of Industrial Engineering and Management 4 (2): 231-257.

Mangla, S. K., P. Kumar, and M. K. Barua. 2015. "Risk Analysis in Green Supply Chain using Fuzzy AHP Approach: A Case Study.” Resources, Conservation and Recycling 104: 375390.

Mangla, S., J. Madaan and F. T. Chan. 2013. "Analysis of Flexible Decision Strategies for Sustainability-Focused Green Product Recovery System.” International Journal of Production Research 51 (11): 3428-3442.

Mangla, S., J. Madaan, P. R. S. Sharma, and M. P. Gupta. 2014. "Multi-Objective Decision Modelling using Interpretive Structural Modelling for Green Supply Chains.” International Journal of Logistics Systems and Management 17 (2): 125-142.

Massoud, M. A., R. Fayad, M. El-Fadel, and R. Kamleh. 2010. "Drivers, Barriers and Incentives to Implementing Environmental Management Systems in the Food Industry: A Case of Lebanon. Journal of Cleaner Production 18 (3): 200-209.

Mathiyazhagan, K., K. Govindan, A. NoorulHaq and Y. Geng. 2013. "An ISM Approach for the Barrier Analysis in Implementing Green Supply Chain Management." Journal of Cleaner Production 47: 283-297.

Miemczyk, J., M. Howard, and T. E. Johnsen. 2016. "Dynamic Development and Execution of Closed-Loop Supply Chains: A Natural Resource-Based View." Supply Chain Management: An International Journal 21 (4): 453-469.

Nasir, M. H. A., A. Genovese, A. A. Acquaye, S. C. L. Koh, and F. Yamoa. 2017. "Comparing Linear and Circular Supply Chains: A Case Study from the Construction Industry." International Journal of Production Economics 183: 443-457.

Pan, S. Y., M. A. Du, I. T. Huang, I. H. Liu, E. E. Chang, and P. C. Chiang. 2015. "Strategies on Implementation of Waste-to-Energy (WTE) Supply Chain for Circular Economy System: A Review." Journal of Cleaner Production 108: 409-421.

Dubey, R., A. Gunasekaran, T. Papadopoulos, S. Fosso Wamba, and S. J. Childe. 2017. "World Class Sustainable Supply Chain Management: Critical Review and Further Research 
Directions." International Journal of Logistics Management, available at: http://doi.org/10.1108/ IJLM-07-2015-0112

Park, J., J. Sarkis, and Z. Wu. 2010. "Creating Integrated Business and Environmental Value within the Context of China's Circular Economy and Ecological Modernization." Journal of Cleaner Production 18 (15): 1494-1501.

Pearce, D. W., and R. K. Turner. 1990. Economics of Natural Resources and the Environment. JHU Press.

Platts, K. W. 1990. Manufacturing Audit in the Process of Strategy Formulation. Ph. D. Thesis, University of Cambridge, Cambridge.

Prendeville, S., G. Hartung, E. Purvis, C. Brass, and A. Hall. 2016. Makespaces: From Redistributed Manufacturing to a Circular Economy. In Sustainable Design and Manufacturing 2016 (pp. 577-588). Springer International Publishing.

Raj, T., R. Shankar, and M. Suhaib. 2010. "GTA-Based Framework for Evaluating the Feasibility of Transition to FMS.” Journal of Manufacturing Technology Management 21 (2): 160-187.

Raut, R. D., B. Narkhede, and B. B. Gardas. 2017. "To Identify the Critical Success Factors of Sustainable Supply Chain Management Practices in the Context of Oil and Gas Industries: ISM Approach.” Renewable and Sustainable Energy Reviews 68: 33-47.

Ravi, V., and R. Shankar. 2005. "Analysis of Interactions among the Barriers of Reverse Logistics." Technological Forecasting and Social Change 72 (8): 1011-1029.

Rizos, V., A. Behrens, T. Kafyeke, M. Hirschnitz-Garbers and A. Ioannou. 2015. "The Circular Economy: Barriers and Opportunities for SMEs". CEPS Working Documents.

Shen, L., X. Song, Y. Wu, S. Liao, and X. Zhang. 2016. "Interpretive Structural Modeling Based Factor Analysis on the Implementation of Emission Trading System in the Chinese Building Sector." Journal of Cleaner Production 127: 214-227.

Shenoy, M. 2016. Industrial Ecology in Developing Countries. In Taking Stock of Industrial Ecology (pp. 229-245). Springer International Publishing

Singh, M., A. Sachdeva, and A. Bhardwaj. 2014. "An Interpretive Structural Modelling Approach for Analysing Barriers in Total Productive Maintenance Implementation." International Journal of Industrial and Systems Engineering 16 (4): 433-450.

Stahel, W. R., 2013. The Business Angle of a Circular Economy e Higher Competitiveness, Higher Resource Security and Material Efficiency. In: A New Dynamic e Effective Business in a Circular Economy, Ellen Macarthur Foundation Report. 
Su, B., A. Heshmati, Y. Geng, and X. Yu. 2013. "A Review of the Circular Economy in China: Moving from Rhetoric to Implementation.”Journal of Cleaner Production 42: 215-227.

Subramanian, N., and A. Gunasekaran. 2015. "Cleaner Supply-Chain Management Practices for Twenty-First-Century Organizational Competitiveness: Practice-Performance Framework and Research Propositions.” International Journal of Production Economics 164: 216-233.

Talib, F., Z. Rahman, and M. N. Qureshi. 2011. "Analysis of Interaction among the Barriers to Total Quality Management Implementation using Interpretive Structural Modelling Approach.” Benchmarking: An International Journal 18 (4): 563-587.

Tripathi, L., A. K. Mishra, A. K. Dubey, C. B. Tripathi, and P. Baredar. 2016. "Renewable Energy: An Overview on Its Contribution in Current Energy Scenario of India.” Renewable and Sustainable Energy Reviews 60: 226-233.

Tukker, A. 2015. "Product Services for A Resource-Efficient and Circular Economy-A Review." Journal of Cleaner Production 97: 76-91.

Venkatesh, V. G., and S. Luthra. 2016. Role of Sustainable Procurement in Sustainable Manufacturing Operations: An Indian Insight. In Strategic Management of Sustainable Manufacturing Operations (pp. 132-148). IGI Global, Chapter 4.

Visvanathan, C., and S. Kumar. 1999. "Issues for Better Implementation of Cleaner production in Asian Small and Medium Industries.” Journal of Cleaner Production 7 (2): 127-134.

Vladimirova, D. 2016. "Waste to Wealth: The Circular Economy Advantage." Production Planning \& Control, Available at: tp://dx.doi.org/10.1080/09537287.2016.1249131.

Wagner, S. M., and N. Neshat. 2010. "Assessing the Vulnerability of Supply Chains using Graph Theory." International Journal of Production Economics 126 (1): 121-129.

Wang, F., H. Yin, and S. Li. 2010. “China's Renewable Energy Policy: Commitments and Challenges. Energy Policy 38 (4): 1872-1878.

Warfield, J. N. 1974. “Toward Interpretation of Complex Structural Models.” IEEE Transactions on Systems, Man, and Cybernetics 4 (5): 405-417.

Watson, R. H. 1978. "Interpretive Structural Modeling-A Useful Tool for Technology Assessment?.” Technological Forecasting and Social Change 11 (2): 165-185.

Williams, K. 2001. “Business as Usual.” Economy and Society 30 (4): 399-411.

Yaduvanshi, N. R., R. Myana, and S. Krishnamurthy. 2016. "Circular Economy for Sustainable Development in India.” Indian Journal of Science and Technology 9 (46): 1-9.

Yuan, Z., J. Bi, and Y. Moriguichi. 2006. “The Circular Economy: A New Development Strategy in China." Journal of Industrial Ecology 10 (1-2): 4-8. 
Zhu, Q., and Y. Geng. 2013. "Drivers and Barriers of Extended Supply Chain Practices for Energy Saving and Emission Reduction among Chinese Manufacturers." Journal of Cleaner Production 40: 6-12.

Zhu, Q., Y. Geng, and K. H. Lai. 2010. "Circular Economy Practices among Chinese Manufacturers Varying in Environmental-Oriented Supply Chain Cooperation and the Performance Implications.” Journal of Environmental Management 91 (6): 1324-1331.

Zhu, Q., Y. Geng, and K. H. Lai. 2011. "Environmental Supply Chain Cooperation and Its Effect on the Circular Economy Practice-Performance Relationship among Chinese Manufacturers." Journal of Industrial Ecology 15 (3): 405-419.

Zhu, Q., Y. Qu, Y. Geng, and T. Fujita. 2017. "A Comparison of Regulatory Awareness and Green Supply Chain Management Practices among Chinese and Japanese Manufacturers.” Business Strategy and the Environment 26 (1): 18-30.

Zhu, Q., J. Sarkis, J. J. Cordeiro, and K. H. Lai. 2008. "Firm-Level Correlates of Emergent Green Supply Chain Management Practices in the Chinese Context.” Omega 36 (4): 577-591.

\section{Annexure-1}

\section{Level Partitioning}

\begin{tabular}{|c|c|c|c|c|}
\hline $\begin{array}{l}\text { Element } \\
\text { P(i) }\end{array}$ & Reachability Set: $\mathbf{R}(\mathbf{P i})$ & Antecedent Set: A(Pi) & $\begin{array}{l}\text { Intersection: } \mathbf{R}(\mathbf{P i}) \\
\& \mathbf{A}(\mathbf{P i})\end{array}$ & $\begin{array}{l}\text { Lev } \\
\text { el }\end{array}$ \\
\hline (1) & $\begin{array}{l}1,3,5,6,7,8,9,10,11,12,13,14,15 \\
16\end{array}$ & $1,2,4,5$ & (2) & \\
\hline 2 & $\begin{array}{l}1,2,3,4,5,6,7,8,9,10,11,12,13,1 \\
4,15,16\end{array}$ & 2,4 & 2,4 & \\
\hline 3 & $3,6,7,8,9,10,11,12,13,14,15,16$ & $1,2,3,4,5$ & 3 & \\
\hline 4 & $\begin{array}{l}1,2,3,4,5,6,7,8,9,10,11,12,13,1 \\
4,15,16\end{array}$ & 2,4 & 2,4 & \\
\hline 5 & $\begin{array}{l}1,3,5,6,7,8,9,10,11,12,13,14,15 \\
16\end{array}$ & $1,2,4,5$ & 1,5 & \\
\hline 6 & $6,7,8,9,10,11,12,13,14,15,16$ & $1,2,3,4,5,6,12$ & 6,12 & \\
\hline 7 & $7,8,9,10,11,14,15,16$ & $1,2,3,4,5,6,7,8,9,10,12,13,15$ & $7,8,9,10,15$ & \\
\hline 8 & $7,8,9,10,11,14,15,16$ & $1,2,3,4,5,6,7,8,9,10,12,13,15$ & $7,8,9,10,15$ & \\
\hline 9 & $7,8,9,10,11,14,15,16$ & $1,2,3,4,5,6,7,8,9,10,12,13,15$ & $7,8,9,10,15$ & \\
\hline 10 & $7,8,9,10,11,14,15,16$ & $1,2,3,4,5,6,7,8,9,10,12,13,15$ & $7,8,9,10,15$ & \\
\hline 11 & $11,14,16$ & $\begin{array}{l}1,2,3,4,5,6,7,8,9,10,11,12,13,14,1 \\
5\end{array}$ & 11,14 & \\
\hline 12 & $6,7,8,9,10,11,12,13,14,15,16$ & $1,2,3,4,5,6,12$ & 6,12 & \\
\hline 13 & $7,8,9,10,11,13,14,15,16$ & $1,2,3,4,5,6,12,13$ & 13 & \\
\hline 14 & $11,14,16$ & $1,2,3,4,5,6,7,8,9,10,11,12,13,14,1$ & 11,14 & \\
\hline
\end{tabular}




\begin{tabular}{|l|l|l|l|l|} 
& & 5 & & \\
\hline 15 & $7,8,9,10,11,14,15,16$ & $1,2,3,4,5,6,7,8,9,10,12,13,15$ & $7,8,9,10,15$ & \\
\hline & & $1,2,3,4,5,6,7,8,9,10,11,12,13,14,1$ & & \\
16 & 16 & 5,16 & 16 & $\mathrm{I}$ \\
\hline
\end{tabular}

\begin{tabular}{|c|c|c|c|c|}
\hline $\begin{array}{c}\text { Element } \\
\mathbf{P}(\mathbf{i})\end{array}$ & Reachability Set R(Pi) & Antecedent Set: A(Pi) & $\begin{array}{l}\text { Intersection R(Pi) \& } \\
\mathbf{A}(\mathbf{P i})\end{array}$ & $\begin{array}{l}\text { Lev } \\
\text { el }\end{array}$ \\
\hline 1 & $\begin{array}{l}1,3,5,6,7,8,9,10,11,12,13,14,1 \\
5\end{array}$ & $1,2,4,5$ & 1,5 & \\
\hline 2 & $\begin{array}{l}1,2,3,4,5,6,7,8,9,10,11,12,13, \\
14,15\end{array}$ & 2,4 & 2,4 & \\
\hline 3 & $3,6,7,8,9,10,11,12,13,14,15$ & $1,2,3,4,5$ & 3 & \\
\hline 4 & $\begin{array}{l}1,2,3,4,5,6,7,8,9,10,11,12,13, \\
14,15\end{array}$ & 2,4 & 2,4 & \\
\hline 5 & $\begin{array}{l}1,3,5,6,7,8,9,10,11,12,13,14,1 \\
5\end{array}$ & $1,2,4,5$ & 1,5 & \\
\hline 6 & $6,7,8,9,10,11,12,13,14,15$ & $1,2,3,4,5,6,12$ & 6,12 & \\
\hline 7 & $7,8,9,10,11,14,15$ & $1,2,3,4,5,6,7,8,9,10,12,13,15$ & $7,8,9,10,15$ & \\
\hline 8 & $7,8,9,10,11,14,15$ & $1,2,3,4,5,6,7,8,9,10,12,13,15$ & $7,8,9,10,15$ & \\
\hline 9 & $7,8,9,10,11,14,15$ & $1,2,3,4,5,6,7,8,9,10,12,13,15$ & $7,8,9,10,15$ & \\
\hline 10 & $7,8,9,10,11,14,15$ & $1,2,3,4,5,6,7,8,9,10,12,13,15$ & $7,8,9,10,15$ & \\
\hline 11 & 11,14 & $\begin{array}{l}1,2,3,4,5,6,7,8,9,10,11,12,13 \\
14,15\end{array}$ & 11,14 & II \\
\hline 12 & $6,7,8,9,10,11,12,13,14,15$ & $1,2,3,4,5,6,12$ & 6,12 & \\
\hline 13 & $7,8,9,10,11,13,14,15$ & $1,2,3,4,5,6,12,13$ & 13 & \\
\hline 14 & 11,14 & $\begin{array}{l}1,2,3,4,5,6,7,8,9,10,11,12,13 \\
14,15\end{array}$ & 11,14 & II \\
\hline 15 & $7,8,9,10,11,14,15$ & $1,2,3,4,5,6,7,8,9,10,12,13,15$ & $7,8,9,10,15$ & \\
\hline
\end{tabular}

\begin{tabular}{|c|c|c|c|c|}
\hline \multicolumn{5}{|c|}{$3^{\text {rd }}$ Iteration } \\
\hline $\begin{array}{l}\text { Element } \\
\text { P(i) }\end{array}$ & Reachability Set R(Pi) & Antecedent Set: A(Pi) & $\begin{array}{l}\text { Intersection } \mathbf{R}(\mathbf{P i}) \boldsymbol{\&} \\
\mathbf{A}(\mathbf{P i})\end{array}$ & $\begin{array}{l}\text { Leve } \\
\text { l }\end{array}$ \\
\hline 1 & $1,3,5,6,7,8,9,10,12,13,15$ & $1,2,4,5$ & 1,5 & \\
\hline 2 & $\begin{array}{l}1,2,3,4,5,6,7,8,9,10,12,13,1 \\
5\end{array}$ & 2,4 & 2,4 & \\
\hline 3 & $3,6,7,8,9,10,12,13,15$ & $1,2,3,4,5$ & 3 & \\
\hline 4 & $\begin{array}{l}1,2,3,4,5,6,7,8,9,10,12,13,1 \\
5\end{array}$ & 2,4 & 2,4 & \\
\hline 5 & $1,3,5,6,7,8,9,10,12,13,15$ & $1,2,4,5$ & 1,5 & \\
\hline 6 & $6,7,8,9,10,12,13,15$ & $1,2,3,4,5,6,12$ & 6,12 & \\
\hline 7 & $7,8,9,10,15$ & $\begin{array}{l}1,2,3,4,5,6,7,8,9,10,12,13,1 \\
5\end{array}$ & $7,8,9,10,15$ & III \\
\hline 8 & $7,8,9,10,15$ & $\begin{array}{l}1,2,3,4,5,6,7,8,9,10,12,13,1 \\
5\end{array}$ & $7,8,9,10,15$ & III \\
\hline 9 & $7,8,9,10,15$ & $\begin{array}{l}1,2,3,4,5,6,7,8,9,10,12,13,1 \\
5\end{array}$ & $7,8,9,10,15$ & III \\
\hline 10 & $7,8,9,10,15$ & $\begin{array}{l}1,2,3,4,5,6,7,8,9,10,12,13,1 \\
5\end{array}$ & $7,8,9,10,15$ & III \\
\hline 12 & $6,7,8,9,10,12,13,15$ & $1,2,3,4,5,6,12$ & 6,12 & \\
\hline 13 & $7,8,9,10,13,15$ & $1,2,3,4,5,6,12,13$ & 13 & \\
\hline 15 & $7,8,9,10,15$ & $\begin{array}{l}1,2,3,4,5,6,7,8,9,10,12,13,1 \\
5\end{array}$ & $7,8,9,10,15$ & III \\
\hline
\end{tabular}

$4^{\text {th }}$ Iteration
\begin{tabular}{|c|l|l|l|l|}
\hline Element P(i) & Reachability Set R(Pi) & Antecedent Set: A(Pi) & Intersection R(Pi) \& A(Pi) & Level \\
\hline 1 & $1,3,5,6,12,13$ & $1,2,4,5$ & 1,5 & \\
\hline 2 & $1,2,3,4,5,6,12,13$ & 2,4 & 2,4 & \\
\hline
\end{tabular}




\begin{tabular}{|l|l|l|l|l|}
3 & $3,6,12,13$ & $1,2,3,4,5$ & 3 & \\
\hline 4 & $1,2,3,4,5,6,12,13$ & 2,4 & 2,4 & \\
\hline 5 & $1,3,5,6,12,13$ & $1,2,4,5$ & 1,5 & \\
\hline 6 & $6,12,13$ & $1,2,3,4,5,6,12$ & 6,12 & \\
\hline 12 & $6,12,13$ & $1,2,3,4,5,6,12$ & 6,12 & \\
\hline 13 & 13 & $1,2,3,4,5,6,12,13$ & 13 & IV \\
\hline
\end{tabular}

$5^{\text {th }}$ Iteration
\begin{tabular}{|c|l|l|l|l|}
\hline Element P(i) & Reachability Set R(Pi) & Antecedent Set: A(Pi) & Intersection R(Pi) \& A(Pi) & Level \\
\hline 1 & $1,3,5,6,12$ & $1,2,4,5$ & 1,5 & \\
\hline 2 & $1,2,3,4,5,6,12$ & 2,4 & 2,4 & \\
\hline 3 & $3,6,12$ & $1,2,3,4,5$ & 3 & \\
\hline 4 & $1,2,3,4,5,6,12$ & 2,4 & 2,4 & \\
\hline 5 & $1,3,5,6,12$ & $1,2,4,5$ & 1,5 & V \\
\hline 6 & 6,12 & $1,2,3,4,5,6,12$ & 6,12 & V \\
\hline 12 & 6,12 & $1,2,3,4,5,6,12$ & 6,12 & \\
\hline
\end{tabular}

$6^{\text {th }}$ Iteration

\begin{tabular}{|c|l|l|l|l|}
\hline Element P(i) & Reachability Set R(Pi) & Antecedent Set: A(Pi) & Intersection R(Pi) \& A(Pi) & Level \\
\hline 1 & $1,3,5$ & $1,2,4,5$ & 1,5 & \\
\hline 2 & $1,2,3,4,5$ & 2,4 & 2,4 & \\
\hline 3 & 3 & $1,2,3,4,5$ & 3 & VI \\
\hline 4 & $1,2,3,4,5$ & 2,4 & 2,4 & \\
\hline 5 & $1,3,5$ & $1,2,4,5$ & 1,5 & \\
\hline
\end{tabular}

$7^{\text {th }}$ Iteration

\begin{tabular}{|c|l|l|l|l|}
\hline Element P(i) & Reachability Set R(Pi) & Antecedent Set: A(Pi) & Intersection R(Pi) \& A(Pi) & Level \\
\hline 1 & 1,5 & $1,2,4,5$ & 1,5 & VII \\
\hline 2 & $1,2,4,5$ & 2,4 & 2,4 & \\
\hline 4 & $1,2,4,5$ & 2,4 & 2,4 & \\
\hline 5 & 1,5 & $1,2,4,5$ & 1,5 & VII \\
\hline
\end{tabular}

$\mathbf{8}^{\text {th }}$ Iteration

\begin{tabular}{|c|l|l|l|l|}
\hline Element P(i) & Reachability Set R(Pi) & Antecedent Set: A(Pi) & Intersection R(Pi) \& A(Pi) & Level \\
\hline 2 & 2,4 & 2,4 & 2,4 & VIII \\
\hline 4 & 2,4 & 2,4 & 2,4 & VIII \\
\hline
\end{tabular}




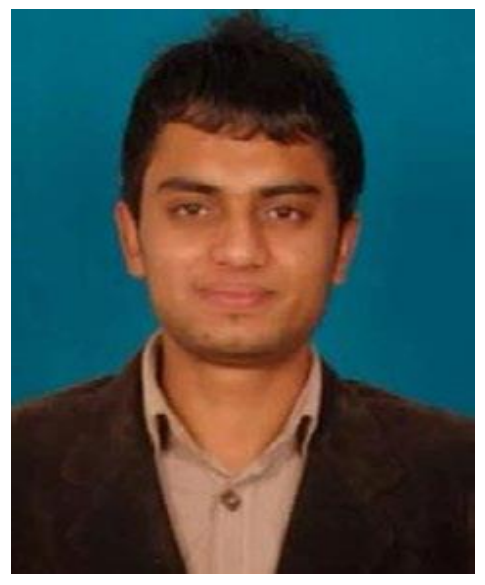

Dr. Sachin Kumar Mangla is working in the field of Green Supply Chain/Smart Manufacturing/Machine Learning/Risk Management/Simulation/Optimization/Reverse Logistics/Renewable Energy Systems/MCDM. His teaching interests are: Total Quality Management \& Six Sigma; Smart Manufacturing; Supply Chain Network Design and Management/Green/Sustainable Supply Chain Management; Decision Support Models; Process Planning and Sequencing; Operations Management. He has published/presented more than 75 papers in repute international/national journals (RSER, TRE-D, JCP, PPC, IJPR, IJPE, PPC, RCR, IJOR, IJLSM, and JFSM) and conferences (POMS, SOMS, IIIE, GLOGIFT). He has an h-index 13, i10-index 14, Google Scholar Citations of 400.

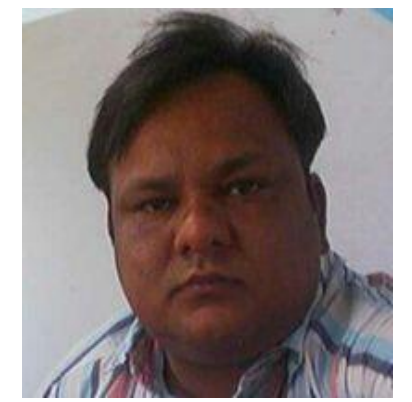

Dr. Sunil Luthra is working as an Assistant Professor, Government Engineering College, Nilokheri, Haryana, India. He has been associated with teaching for the last fifteen years. He has contributed over ninety research papers in international referred \& national journals, and conferences at international and national level. His scholarly work has also been acknowledged in several International journals of repute such as the IJPE, JCP, PPC, RSER, EGY, RCR, JRPO and many more, and conference of repute like SOM-14, NITIE - POMS, AGBA, GLOGIFT 14 and GLOGIFT 15 etc. His research is in spotlight. His works got over 940 Citations (h-index=16). His RG score is higher than $82.5 \%$ of Research Gate members. His specific areas of interest are operation management; green supply chain management; sustainable supply chain management; sustainable consumption and production; reverse logistics; renewable/sustainable energy technologies and business sustainability etc. 


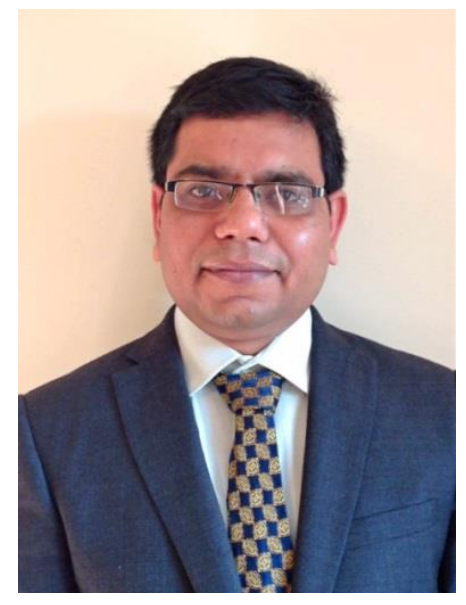

Nishikant Mishra is a Professor in Operations and Supply Chain Management at Hull University Business School, University of Hull. Prior to that he was Senior Lecturer in Operations \& Supply Chain Management and Director of Post Graduate Research at Norwich Business School, University of East Anglia, Norwich. He worked as a Senior Lecturer and Director of Research at School of Management \& Business, Aberystwyth University. He has worked on numerous consultancy projects funded by British Council, Biotechnology and Biological Sciences Research Council (BBSRC), British Academy (BA), Innovate UK, Department for Environment, Food and Rural Affairs (DEFRA), Higher Education Academy (HEA) and Meat Promotion Wales (HCC). His research articles have been published in various renowned journals of Operations Research and Operations \& Supply chain Management.

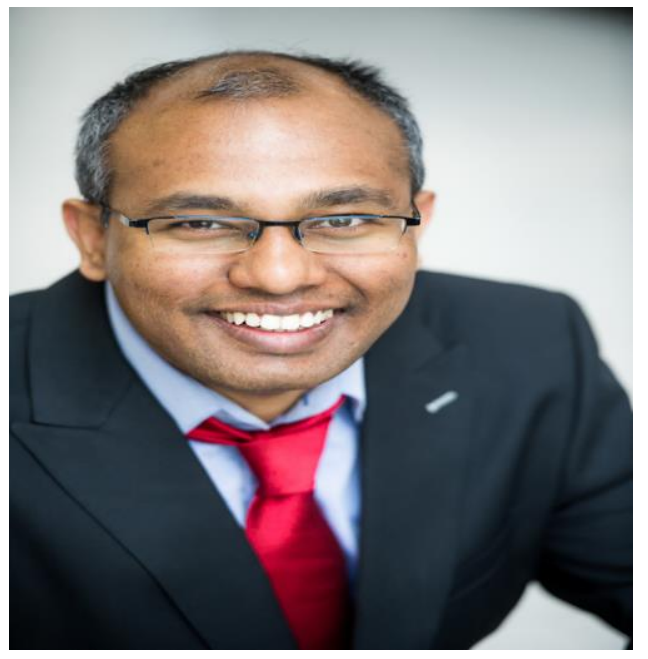

Akshit Singh is a Lecturer in Management Sciences at Alliance Manchester Business School, University of Manchester. His $\mathrm{PhD}$ is in Operations and Supply Chain Management at University of East Anglia, Norwich. He did his M.Sc. from University of Nottingham, UK and Bachelor's degree from National Institute of Technology, Kurukshetra, India. His research is close to implementation side and he is also involved in consultancy work. His research articles have been published in renowned journals such as International Journal of Production Economics, Annals of Operation Research and Robotics and Computer-Integrated Manufacturing.

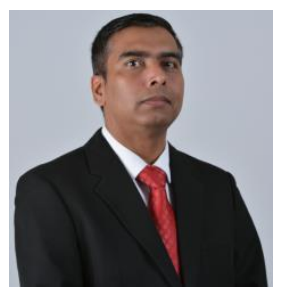

Nripendra P. Rana is Associate Professor in the School of Management at Swansea University, UK. With an academic and professional background in Mathematics and Computer Science and with $\mathrm{PhD}$ in Information Systems, his current research interests focus primarily upon adoption of emerging and cutting edge technology, e-government, m-government, e-commerce and mcommerce systems. His work has been published in leading academic journals including European Journal of Marketing, Information Systems Frontiers, Government Information Quarterly, Production Planning \& Control, Journal of Business Research, Public Management Review and Computers in Human Behavior. He has also presented his research in some of the prominent international conferences of information systems across the world. 


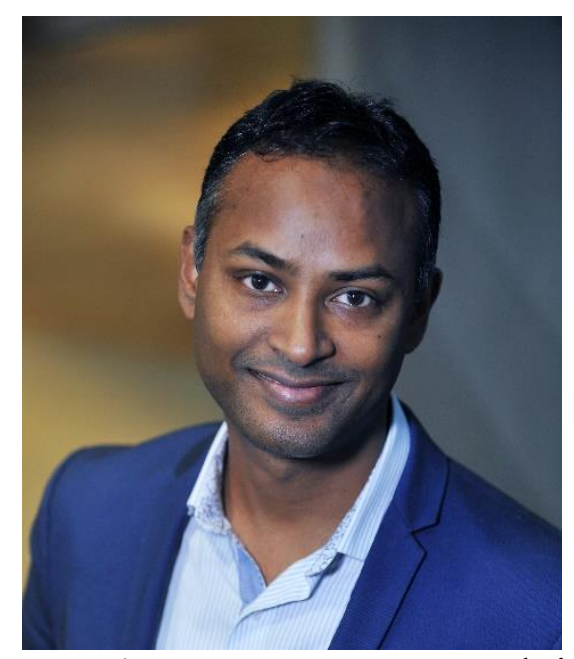

Manoj Dora's current research is focused on how we can switch from our current industrial "linear" model to a circular economy using cross-cutting operational improvement methodologies. Dr Dora has significant practical experience and interdisciplinary research publications in the field of sustainable food supply chain management and food security. Manoj has been successful in acquiring research grants from the World Bank, European Commission (FP7), British Academy and several private companies in the past.

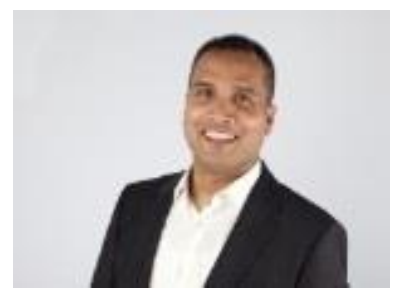

Yogesh K. Dwivedi is a Professor of Digital Marketing and Innovation, Director of the Emerging Markets Research Centre (EMaRC), and Director of Research in the School of Management at Swansea University, Wales, UK. His research interests are in the area of Information Systems (IS) including digital and social media marketing particularly in the context of emerging markets. He has published more than 250 articles in a range of leading academic journals and conferences. He has co-edited/co-authored more than 20 books; acted as co-editor of fifteen journal special issues; organised tracks, mini-tracks and panels in leading conferences; and served as programme co-chair of 2013 IFIP WG 8.6 Conference on Grand Successes and Failures in IT: Public and Private Sectors and Conference Chair of IFIP WG 6.11 I3E2016 Conference on Social Media: The Good, the Bad, and the Ugly. He is an Associate Editor of European Journal of Marketing and Government Information Quarterly and Senior Editor of Journal of Electronic Commerce Research. More information about me can be obtained from: http://www.swansea.ac.uk/staff/som/academic-staff/y.k.dwivedi/. 